\title{
ФОРМАЦИОННАЯ ПРИНАДЛЕЖНОСТЬ КАЛИЕВЫХ ТРАХИАНДЕЗИБАЗАЛЬТОВ ПОБОЧНОГО ИЗВЕРЖЕНИЯ 2012-2013 ГГ. ВУЛКАНА ПЛОСКИЙ ТОЛБАЧИК ПО ГЕОХИМИЧЕСКИМ ПРИЗНАКАМ (КАМЧАТКА)
}

\author{
(C) 2016 г. С. А. Хубуная 1 , Т. С. Еремина ${ }^{1}$, А. В. Соболев 2 \\ ${ }^{1}$ Институт вулканологии и сейсмологии ДВО РАН \\ 683006, Петропавловск-Камчатский, бульвар Пийпа, 9, \\ e-mail: hubsa@kscnet.ru \\ ${ }^{2}$ Институт геохимии и аналитической химии им. В.И. Вернадского РАН \\ 119991, ГСП-1, В-334, Москва, ул. Косыгина, 19 \\ Поступила в редакцию 16.04 .2015 г.
}

\begin{abstract}
Изучены петрографические, минералогические и геохимические особенности К-трахиандезибазальтов побочного извержения 2012-2013 гг. вулкана Плоский Толбачик. К-трахиандезибазальты имеют явные признаки надсубдукционного происхождения. Это глубоко дифференцированные породы, характеризующиеся значительным фракционированием плагиоклаза. Изучение радиогенных изотопных отношений $\mathrm{Sr}, \mathrm{Nd}$ и $\mathrm{Pb}$ в K-трахиандезибазальтах свидетельствует об их мантийном происхождении и отсутствии влияния земной коры на их составы. Проведен сравнительный анализ отношений содержаний некогерентых элементов в К-трахиандезибазальтах, внутриплитных, рифтогенных и островодужных умереннокалиевых базальтах и андезибазальтах к содержанию этих элементов в примитивной мантии. Геохимические особенности К-трахиандезибазальтов позволяют отнести их к надсубдукционной субщелочной формации калиевого ряда.
\end{abstract}

DOI: $10.7868 / \mathrm{S} 0203030616010028$

\section{ВВЕДЕНИЕ}

Одной из проблем магматической геохимии островных дуг и континентальных окраин является выяснение причин пространственной геохимической зональности. В последнее время, в пределах этих планетарных структур выявлены нехарактерные для них (неостроводужные) вулканические комплексы пород разного возраста, которые характеризуются индивидуальными геохимическими признаками. Одни из них имеют K-Na субщелочную или щелочную специфику, характерную для рифтогенного и внутриплитного геохимического типа пород [Волынец и др., 1990, 1995; Перепелов, $2005,2007,2014]$. Другие - характеризуются значительным обогащением легкими литофильными элементами и относятся к внутриплитным К-щелочным или субщелочным геохимическим типам вулканогенных образований. При этом в долгоживущих вулканических центрах может фиксироваться смена островодужных (надсубдукционных) умереннокалиевых вулканических образований на внутриплитные базальтоиды, их субвулканические или интрузивные аналоги и наоборот. Смена продуктов вулканической деятельности различных геохимических типов происходила в течение миллионов лет. По мнению многих исследователей, она была связана с тектонической структурной перестройкой региона: либо с возникновением разрыва субдукционной океанической плиты и появлением тектонического “окна" (slab-window), либо с процессами рифтогенеза, глубокими расколами литосферы. В обоих случаях, вероятно, с помощью плюмов, при формировании подобных магм могли участвовать полигенные, в том числе и глубинные астеносферные источники [Ханчук, Иванов, 1999; Flower, 1998; Перепелов, 2014; и др.].

На южном склоне вулкана Плоский Толбачик 7 мая 1941 г. на высоте 2000 м произошло побочное извержение островодужных (надсубдукционных) умереннокалиевых магнезиальных базальтов [Пийп, 1946; Ермаков, Важеевская, 1973; и др.]. 27 ноября 2012 г., в этом же месте, в непосредственной близости от конуса извержения 1941 г., на высоте 2358 м, произошло побочное извержение калиевых трахиандезибазальтов (ТТИ-50) [Волынец и др., 2013; Гордеев и др., 2013; Двигало и др., 1914; Ермаков и др., 2014; Федотов и др., 2014; Zelenski et al., 2014; и др.]. Смена вулканиче-

${ }^{1}$ ТТИ-50 - Трещинное Толбачинское извержение им. 50-летия образования ИВиС ДВО РАН. Название извержения принято на заседании Ученого совета ИВиС ДВО РАН. 
ских продуктов различных геохимических типов фиксировалась на Толбачинском долу ${ }^{2}$, во время Большого трещинного Толбачинского извержения [Большое трещинное ..., 1984]. Следует подчеркнуть, что извержения на вулкане Толбачик и Толбачинском долу произошли в течение исторического времени, при отсутствии структурной перестройки этого района Камчатки. Сравнение геохимических особенностей К-трахиандезибазальтов с продуктами вулканической деятельности, которые формировались в разных геодинамических обстановках, может помочь решению вопроса их образования и оценке формационной принадлежности.

Изучение К-трахиандезибазальтов имеет и большое практическое значение. Во время их извержения в 2013 г. в килограммовой пробе из лавового потока было отобрано 700 знаков алмазов [Гордеев и др., 2014]. Выяснение геохимической формационной принадлежности этих пород должно помочь изучению условий их образования и, как следствие, возможному обнаружению алмазов в продуктах вулканической деятельности, которые характеризуются такими же геохимическими характеристиками. Особенно актуальным является возможность искусственного получения алмазов на основе применения результатов геохимического изучения условий образования этих редких минералов.

Целью настоящей работы является выяснение геохимической формационной принадлежности К-трахиандезибазальтов. Как известно, тренды распределения несовместимых элементов в магматических породах контролируются содержанием их в источнике и равновесиями минерал-расплав в процессе эволюции исходных магм [Интерпретация ..., 2001]. Для оценки формационной принадлежности сравниваемых вулканитов по геохимическим признакам наиболее надежным методом является построение графиков (спайдердиаграмм), характеризующих отношение концентраций несовместимых элементов в породе к концентрациям этих элементов в примитивной (недеплетированной) мантии, впервые предложенное американскими исследователями при изучении базальтов Тихого океана [Wood, 1979; Holm, 1985]. Это особенно актуально, так как здесь используется весь спектр несовместимых элементов, которые при плавлении источника первыми уходят в расплав. Большая часть несовместимых элементов не имеет минералов-концентраторов при дальнейшей кристаллизации исходных магматических расплавов. Поэтому они являются наиболее информативными для оценки формационной принадлежности исходных магматических расплавов. По этой методике проведено сравнение

\footnotetext{
2 Толбачинский дол - вулканическое плоскогорье в районе вулканов Острый и Плоский Толбачик, на высоте 900 м.
}

геохимических особенностей К-трахиандезибазальтов извержения 2012-2013 гг. с таковыми основных геохимических типов пород различных районов Камчатского полуострова. Сопоставление геохимического и изотопного составов всех рассматриваемых вулканических пород должно помочь выяснению генезиса К-трахиандезибазальтов и интерпретации их источника.

\section{ИССЛЕДОВАННЫЕ ОБРАЗЦЫ И МЕТОДЫ ИХ ИЗУЧЕНИЯ}

Действующий вулкан Плоский Толбачик находится в южной части Ключевской группы вулканов. Объектами исследования послужили лавы, бомбы, пеплы, кристаллические плагиоклазовые лапилли. Образцы отбирались непосредственно во время извержения дежурными вулканологическими отрядами и авторами этой публикации во время полевых работ 2013 г. (рис. 1). При этом, были изучены петрографические, минералогические, геохимические особенности всех вулканических пород. Для изучения главных и редких элементов продукты вулканической деятельности дробились в одной и той же железо-марганцевой ступке, а затем были растерты в яшмовом истирателе.

Детальное исследование породообразующих минералов, оливинов, пироксенов и плагиоклазов К-трахиандезибазальтов было проведено из обогащенных в бромоформе фракций. Часть минералов была изучена в полированных аншлифах. Подробная методика подготовки минералов для их изучения на рентгеноспектральном микроанализаторе описана в [Хубуная и др., 1993].

Главные элементы высококалиевых трахиандезибазальтов ТТИ-50 были исследованы на основе рентгенофлюоресцентного анализа на стеклянных дисках, используя PANanalytical Axios волновой дисперсионный спектрометр в Передовой Инструментальной лаборатории Университета г. Фэрбенкс (Аляска, США). Предварительная калибровка осуществлялась при помощи стандартов AGV-1, BHVO-1, BIR-1, JB-2, JGb-1, JP-1 и JR-1. Часть образцов на главные элементы была проанализирована рентгенофлуоресцентным методом в Институте геохимии и аналитической химии им. В.И. Вернадского (г. Москва) по методике [Рощина и др., 1971].

Определения концентраций элементов-примесей в К-трахиандезибазальтах вулкана Плоский Толбачик проводили в Аналитическом сертификационном испытательном центре "Института проблем технологии микроэлектроники и особо чистых материалов РАН” (АСИЦ ИПТМ РАН, Черноголовка, Россия). Относительное стандартное отклонение для всех определяемых элементов не превышает 0.2 при измерении их содержания 


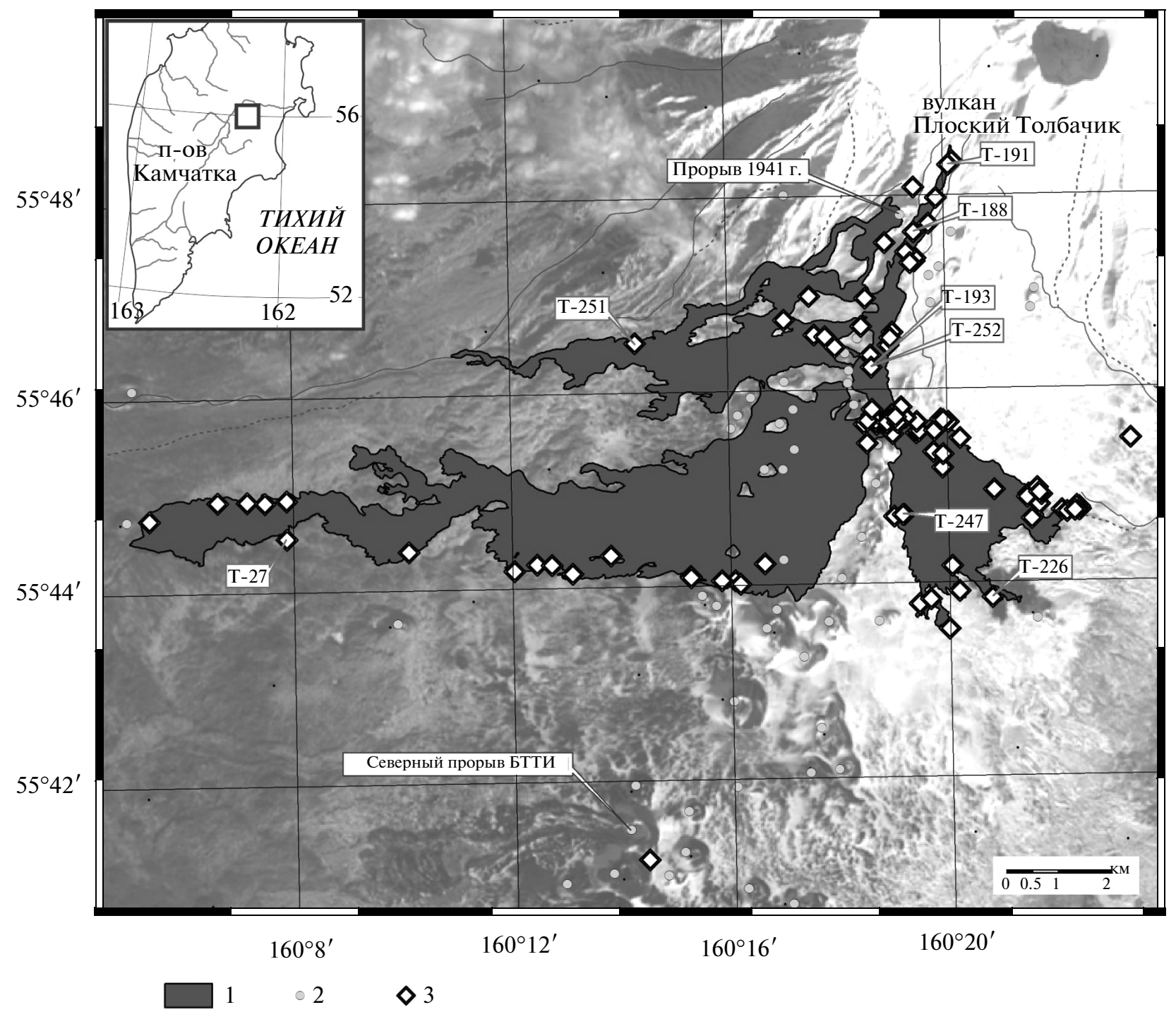

Рис. 1. Схема опробования лавовых потоков побочного извержения (2012-2013 гг.) вулкана Плоский Толбачик. 1 - лавовые потоки К-трахиандезибазальтов; 2 - вершины исторических и доисторических конусов; 3 - точки опробования лавовых потоков и вулканических бомб. Снимок лавовых потоков выполнен на основе фотографического снимка космического спутника ЕО-1, с дополнениями В.Н. Двигало, И.М. Романовой.

до 5 относительных \% и не превышает 0.1 при измерении их содержания >5 относительных \% [Karandashev et al., 2008].

Для определения элементов-примесей в умереннокалиевых базальтах и андезибазальтах был использован метод LA-ICP MS с лазерным пробоотбором. Исследования проводили на массспектрометре ELEMENT-2, Thermo Scientific, c твердотельным лазером UP-213 New Wave Research, в Институте химии им. Макса Планка (г. Майнц, Германия). Погрешность определения концентрации, оцененная по воспроизведению стандарта, не превышала 5 относительных \% (две стандартные ошибки) для содержаний более 1 г/т и 10 относительных \% для концентраций около 0.1 г/т. [Соболев и др., 2009].
Оливины, клинопироксены и плагиоклазы были проанализированы в Институте вулканологии и сейсмологии ДВО РАН на рентгеноспектральном микроанализаторе САМЕВАХ и в Институте химии им. Макса Планка (г. Майнц, Германия) по методике [Соболев и др., 2009].

Измерения изотопного состава $\mathrm{Sr}$ и $\mathrm{Nd}$ проводилось в Институте геохимии и аналитической химии им. В.И. Вернадского (ГЕОХИ РАН, г. Москва) на модифицированном масс-спектрометре TSN 206 SA с трехленточным источником ионов. Измеренные изотопные отношения $\mathrm{Nd}$ нормализованы по ${ }^{150} \mathrm{Nd} /{ }^{142} \mathrm{Nd}=0.209627$, используя $\left({ }^{143} \mathrm{Nd} /{ }^{144} \mathrm{Nd}\right)_{\text {chur }}=$ $=0.512638$. 
Изотопный состав свинца определялся в “Всероссийском научно-исследовательском геологическом институте им. А. П. Карпинского" (ФГУП “ВСЕГЕИ", Санкт-Петербург) методом TIMS термо-эмиссионной масс-спектрометрией на твердофазном масс-спектрометре с твердофазным источником ионизации [Берзина и др., 2013].

\section{ПЕТРОГРАФИЧЕСКАЯ \\ И МИНЕРАЛОГИЧЕСКАЯ ХАРАКТЕРИСТИКА ИССЛЕДУЕМЫХ ПОРОД}

К-трахиандезибазальты побочного извержения 2012-2013 гг. вулкана Плоский Толбачик представляют собой субафировые породы (рис. 2a, 2б). В субафировых разностях суммарное содержание фенокристаллов плагиоклаза, оливина и клинопироксена может достигать 2-3\%. Плагиоклаз представлен таблитчатыми кристаллами, достигающими размера до первых сантиметров. Фенокристаллы плагиоклаза, как правило, имеют прямую зональность, а их составы изменяются от $\mathrm{An}_{51} \mathrm{Ab}_{43} \mathrm{Ort}_{4}$ до $\mathrm{An}_{83} \mathrm{Ab}_{16} \mathrm{Ort}_{1}$. Они зачастую резорбированы стеклом. Особенно следует отметить кристаллические лапилли плагиоклаза, которые извергались, преимущественно, в начальный период извержения. Они представлены сростками плагиоклаза и отдельными пластинками, достигающими размера до 1.5 см (см. рис. 2б, 2в, 2г). Состав пластинок и сростков плагиоклаза, кристаллических лапилли сильно варьирует. Для них характерна ячеистая структура химических составов. Отдельные соседние участки, граничащие друг с другом, в пластинке плагиоклаза могут сильно отличаться по составу, от $\mathrm{An}_{60} \mathrm{Ab}_{36} \mathrm{Ort}_{3}$ до $\mathrm{An}_{80} \mathrm{Ab}_{19}$ Ort $_{1 .}$ Зональность в подобных пластинках плагиоклаза отсутствует. Отдельные пластинки и сростки лапилли плагиоклаза по форме напоминают таковые Южного прорыва БТТИ [Большое трещинное ..., 1984] и кальдерного вершинного извержения вулкана Плоский Толбачик [Мархинин и др., 1973], но они меньше по размеру. В задачу настоящей работы не входит изучение кристаллографического феномена лапилли плагиоклазов. Фенокристаллы оливина и авгита встречаются в резко подчиненном количестве. Максимальный размер этих минералов достигает 1 мм. Магнезиальность фенокристаллов оливинов лежит в пределах $\mathrm{Fo}_{77-69}$ (рис. 3). Фенокристаллы клинопироксена отвечают авгиту, $\mathrm{Mg} \# 78-$ 69 (рис. 3). Проведенный петрографический анализ позволяет считать, что оливины и клинопироксены кристаллизовались в последнюю очередь, вслед за плагиоклазом. Основная масса трахиандезибазальтов представляет собой пористое вещество, бурое в проходящем свете, в котором располагаются игольчатые микролиты плагиоклаза, оливина, авгита и магнетита.

\section{ГЕОХИМИЧЕСКИЕ ОСОБЕННОСТИ К-ТРАХИАНДЕЗИБАЗАЛЬТОВ И УМЕРЕННОКАЛИЕВЫХ БАЗАЛЬТОВ И АНДЕЗИБАЗАЛЬТОВ}

На классификационной диаграмме в [Петрографический кодекс ..., 2009] фигуративные точки вулканических пород побочного извержения 2012-2013 гг. вулкана плоский Толбачик располагаются в поле трахиандезибазальтов (рис. 4). При этом, повышение $\mathrm{SiO}_{2}$ в трахиандезибазальтах приводит к повышению в них щелочей. По существу, они лежат на продолжении тренда высококалиевых глиноземистых базальтов ${ }^{3}$ (трахибазальтов) Южного прорыва БТТИ, 1975-1976 гг. [Большое трещинное ..., 1984]. Содержание $\mathrm{Na}_{2} \mathrm{O}$ в К-трахиандезибазальтах близко к таковым известково-щелочной умереннокалиевой серии (табл. 1). В то же время, концентрации $\mathrm{K}_{2} \mathrm{O}$ в трахиандезибазальтах превышают содержания таковых в умереннокалиевых породах в 2-2.7 раза (см. табл. 1). Высокие содержания $\mathrm{K}_{2} \mathrm{O}$ в породах извержения 2012-2013 гг. приводят к тому, что фигуративные точки их составов попадают в поле трахиандезибазальтов (см. рис. 4). Кроме того, на диаграмме в работе Дж. Гилла [Gill, 1970] рассматриваемые породы попадают в поле высококалиевой серии. Эти геохимические особенности трахиандезибазальтов побочного извержения 2012-2013 гг. вулкана Плоский Толбачик позволяют называть их калиевыми трахиандезибазальтами (К-трахиандезибазальты).

Характер распределения несовместимых элементов К-трахиандезибазальтов на спайдердиаграмме характеризуется Th-, Ce-, Sr-минимумами, отчетливыми минимумами высокозарядных элементов $\mathrm{Nb}$, Ta, Ti и Rb-, U-, Pb-максимумами (рис. 5).

Фигуративные точки базальтов и андезибазальтов вулканов: Ключевской, Плоский Толбачик, Харчинский располагаются в поле умереннокалиевой серии пород (см. рис. 4). Геохимические и минералогические особенности этих пород в литературе рассмотрены достаточно подробно [Ермаков, Важеевская, 1973; Хубуная и др., 1993, 1998, 2007; Kersting, Arkulus, 1994; Арискин и др., 1995; Волынец и др., 1999; Миронов, 2009; и др.]. По петрографическим характеристикам, набору и составу породообразующих минералов, содержанию главных элементов и элементов-примесей они близки (табл. 2). Минералогические особенности этих пород отличают их от большинства островодужных вулканических образований. Во всех сравниваемых умереннокалиевых магнезиальных и глиноземистых базальтах и андезибазальтах присутствуют высокомагнезиальные $\left(\mathrm{Fo}_{91-88}\right)$ оливины с

\footnotetext{
${ }^{3}$ Названия пород приводятся в интерпретации авторов [Большое трещинное ..., 1986].
} 

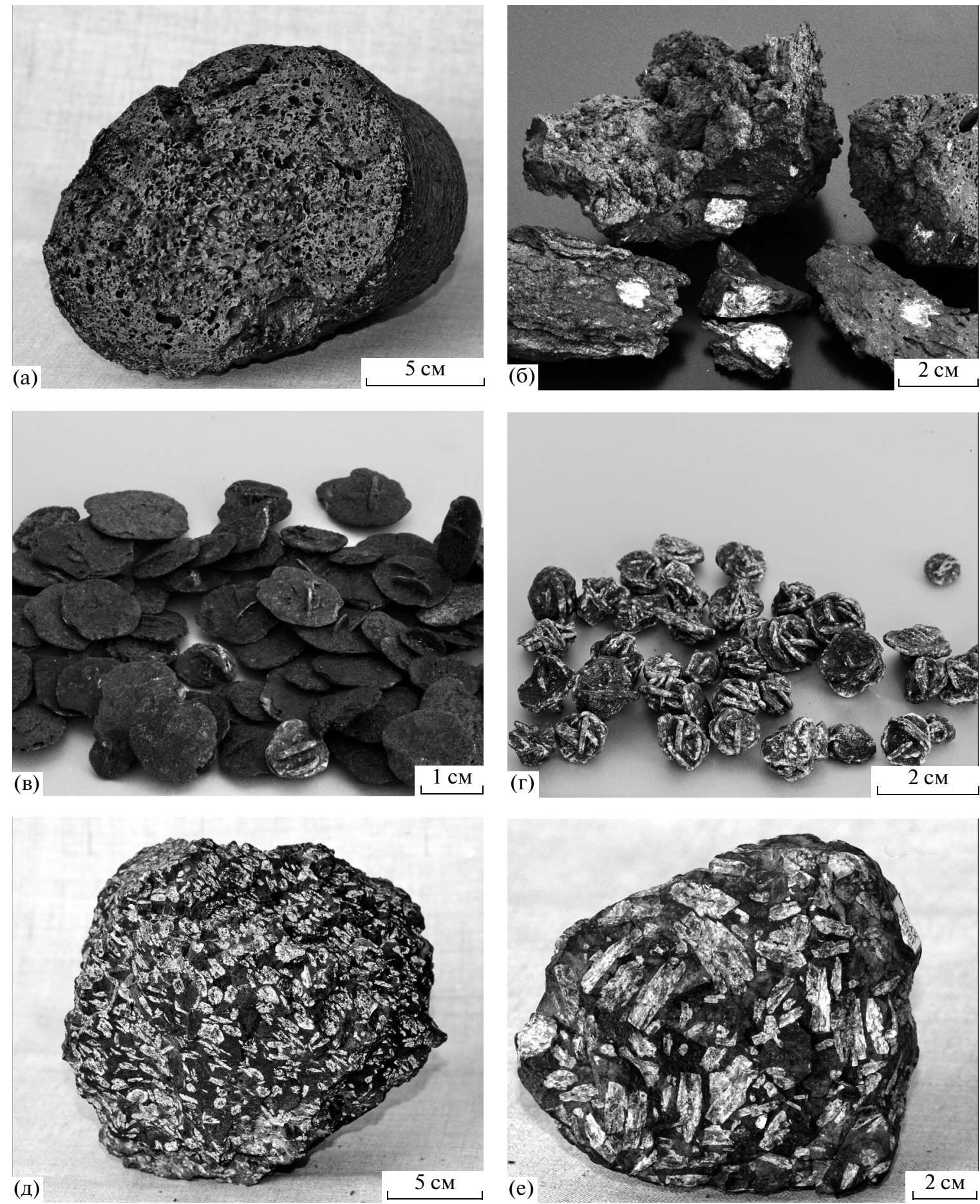

Рис. 2. Продукты вулканической деятельности побочного извержения 2012-2013 гг. вулкана Плоский Толбачик. а - вулканическая бомба субафирового К-трахиандезибазальта (№ Т-95); б - субафировые К-трахиандезибазальты (№ T-256); в - пластинки лапилли плагиоклаза (№ Т-253); г - сростки лапилли плагиоклаза (№ ГФ-254); д - плагиоклазовый кумулат из вулканической бомбы первого конуса Северного прорыва БТТИ (№ 101-83); е - плагиоклазовый кумулат из вулканической бомбы прорыва Лавовый Шиш, вулкан Сопка Дальняя (№ 101-14), коллекция Б.И. Пийпа. 


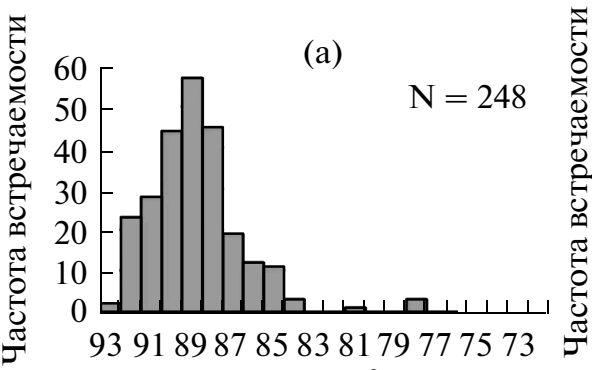

$\mathrm{Mg} \times 100 / \mathrm{Mg}+\mathrm{Fe}^{2+}$, мол. $\%$

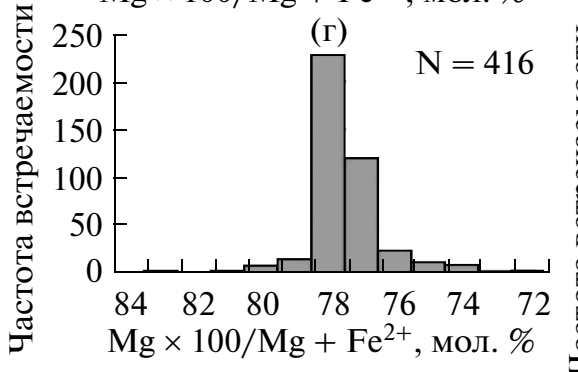

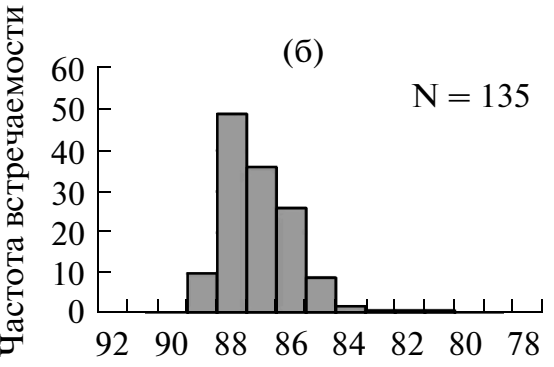

$\mathrm{Mg} \times 100 / \mathrm{Mg}+\mathrm{Fe}^{2+}$, мол. $\%$

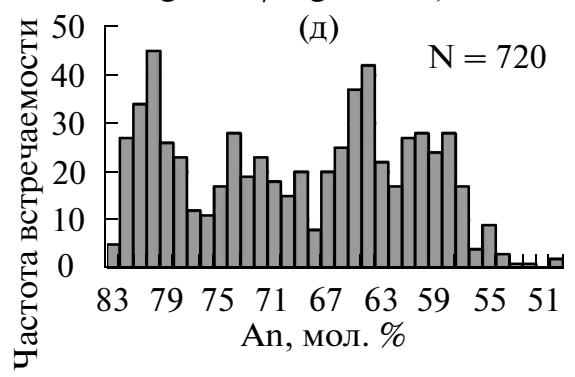

(в)

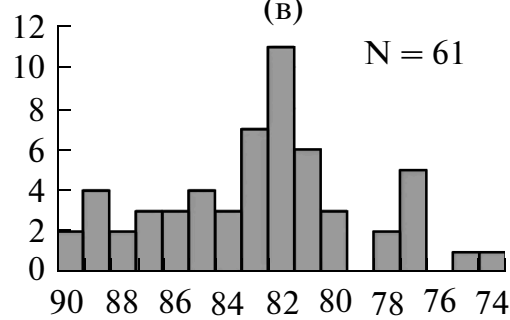

$\mathrm{Mg} \times 100 / \mathrm{Mg}+\mathrm{Fe}^{2+}$, мол. $\%$

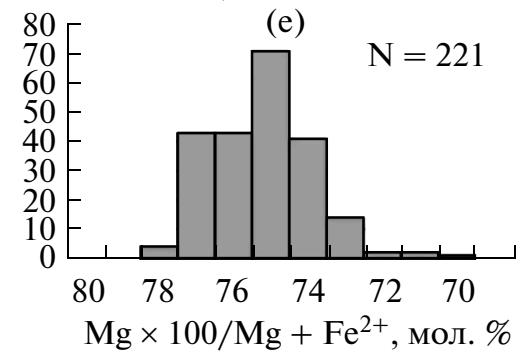

Рис. 3. Составы минералов базальтов и К-трахиандезибазальтов Ключевской группы вулканов.

а - оливины умереннокалиевого магнезиального базальта лавового потока, конус б/н, (№ 11-3), вулкан Ключевской; б - оливины умереннокалиевого магнезиального базальта лавового потока, второго конуса Северного прорыва БТТИ (№ 101-88), Толбачинский дол. Вулкан Плоский Толбачик: в - оливины умереннокалиевого магнезиального базальта лавового потока, побочного прорыва 1941 г. (№ 101-29); к - К-трахиандезибазальт (Т-191): г - оливины, д - плагиоклазы, е - клинопироксены. N - количество измерений. Название конуса вулкана Ключевской соответствуют таковому [Ермаков, 1977].

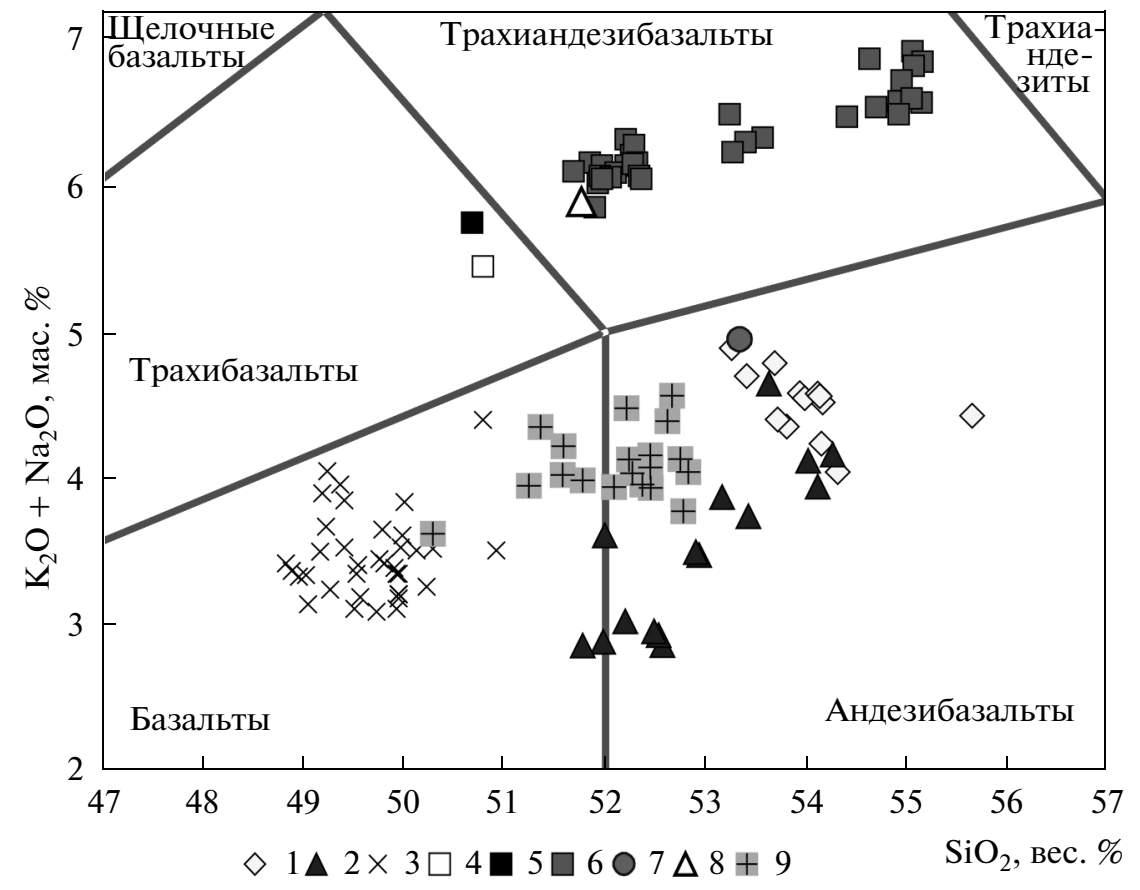

Рис. 4. Составы пород вулканов Ключевской группы на фрагменте классификационной диаграмме $\left(\mathrm{K}_{2} \mathrm{O}+\mathrm{Na}_{2} \mathrm{O}\right)-$ $\mathrm{SiO}_{2}$ [Петрографический кодекс ..., 2009]. Вулкан Ключевской: 1 - умереннокалиевые глиноземистые андезибазальты; 2 - умереннокалиевые магнезиальные базальты и андезибазальты. Толбачинский дол: 3 - умереннокалиевые магнезиальные базальты, Северный прорыв БТТИ; 4, 5 - средние составы субщелочных глиноземистых базальтов, Южный прорыв БТТИ [Большое Трешинное ..., 1984]. Вулкан Плоский Толбачик: 6 - К-трахиандезибазальты побочного прорыва 2012-2013 гг., 7 - умереннокалиевый глиноземистый андезибазальт из геологического разреза вулкана (№ 974 ГФ); 8 - К-трахиандезибазальт побочного прорыва 2012-2013 гг. [Zelenski et.al., 2014]; 9 - умереннокалиевые магнезиальные базальты и андезибазальты из геологического разреза вулкана Харчинский. 
Таблица 1. Представительные составы лавовых потоков К-трахиандезибазальтов побочного извержения $2012-$ 2013 гг. вулкана Плоский Толбачик

\begin{tabular}{|c|c|c|c|c|c|c|c|}
\hline Элемент/№№ & $\mathrm{T}-193$ & $\mathrm{~T}-246$ & $\mathrm{~T}-252$ & T-191 & $\mathrm{T}-188$ & $\mathrm{~T}-251$ & $\mathrm{~T}-27$ \\
\hline $\mathrm{SiO}_{2}$ & 51.89 & 51.86 & 52.12 & 54.399 & 54.688 & 54.91 & 52.62 \\
\hline $\mathrm{TiO}_{2}$ & 2.02 & 2.02 & 1.82 & 1.78 & 1.78 & 1.58 & 1.97 \\
\hline $\mathrm{Al}_{2} \mathrm{O}_{3}$ & 16.21 & 16.03 & 16.92 & 16.42 & 16.65 & 17.32 & 15.91 \\
\hline $\mathrm{FeO}$ & 11.39 & 11.93 & 10.68 & 9.05 & 9.13 & 9.81 & 10.25 \\
\hline $\mathrm{MnO}$ & 0.18 & 0.15 & 0.15 & 0.17 & 0.17 & 0.14 & 0.18 \\
\hline $\mathrm{MgO}$ & 4.24 & 4.25 & 2.71 & 3.05 & 3.05 & 3.01 & 3.92 \\
\hline $\mathrm{CaO}$ & 7.58 & 7.41 & 7.61 & 6.92 & 6.94 & 7.05 & 7.58 \\
\hline $\mathrm{Na}_{2} \mathrm{O}$ & 3.41 & 3.93 & 3.86 & 3.78 & 3.82 & 4.01 & 3.45 \\
\hline $\mathrm{K}_{2} \mathrm{O}$ & 2.45 & 2.47 & 2.23 & 2.69 & 2.72 & 2.48 & 2.46 \\
\hline $\mathrm{P}_{2} \mathrm{O}_{5}$ & 0.61 & 0.48 & 0.53 & 0.65 & 0.65 & 0.57 & 0.66 \\
\hline Сумма & 99.98 & 100.53 & 98.63 & 98.92 & 99.59 & 100.88 & 99.00 \\
\hline $\mathrm{Rb}$ & 71 & 76 & 58 & 68 & 72 & 57 & 59 \\
\hline $\mathrm{Ba}$ & 617 & 536 & 543 & 613 & 609 & 567 & 550 \\
\hline Th & 3.1 & 3.0 & 3.2 & 3.5 & 3.6 & 3.4 & 3.3 \\
\hline $\mathrm{U}$ & 1.8 & 1.7 & 1.9 & 2.0 & 2.0 & 1.9 & 1.9 \\
\hline $\mathrm{Nb}$ & 7.6 & 7.2 & 8.8 & 8.7 & 8.8 & 8.7 & 8.6 \\
\hline $\mathrm{Ta}$ & 0.50 & 0.45 & 0.55 & 0.63 & 0.66 & 0.62 & 0.57 \\
\hline K & 20338 & 20504 & 18512 & 22331 & 22605 & 20587 & 20421 \\
\hline $\mathrm{La}$ & 24.3 & 22.0 & 22.9 & 24.2 & 23.7 & 22.5 & 22.7 \\
\hline $\mathrm{Ce}$ & 60.3 & 58.9 & 57.8 & 61.1 & 61.4 & 55.7 & 58 \\
\hline $\mathrm{Pb}$ & 7.3 & 7.2 & 7.5 & 8.7 & 8.7 & 8.2 & 7.5 \\
\hline $\operatorname{Pr}$ & 8.0 & 7.8 & 8.3 & 8.5 & 8.5 & 7.9 & 8.2 \\
\hline $\mathrm{Nd}$ & 37.8 & 35.8 & 37.8 & 39.2 & 39.9 & 36.5 & 37.8 \\
\hline $\mathrm{Sr}$ & 329 & 318 & 300 & 321 & 324 & 296 & 311 \\
\hline $\mathrm{Sm}$ & 8.9 & 8.4 & 9.2 & 9.4 & 9.6 & 9.0 & 9.1 \\
\hline $\mathrm{Zr}$ & 289 & 265 & 290 & 309 & 308 & 290 & 280 \\
\hline $\mathrm{Hf}$ & 6.4 & 5.6 & 7.0 & 7.3 & 7.4 & 7.3 & 6.9 \\
\hline $\mathrm{Eu}$ & 2 & 2 & 3 & 3 & 3 & 2 & 2.5 \\
\hline $\mathrm{Ti}$ & 12108 & 12108 & 10909 & 10669 & 10669 & 94706 & 11808 \\
\hline $\mathrm{Gd}$ & 9.1 & 8.7 & 9.4 & 9.8 & 10.0 & 9.1 & 9.2 \\
\hline $\mathrm{Tb}$ & 1.4 & 1.3 & 1.4 & 1.5 & 1.5 & 1.4 & 1.4 \\
\hline Dy & 8.1 & 7.6 & 8.6 & 8.8 & 9.0 & 8.3 & 8.3 \\
\hline Ho & 1.7 & 1.5 & 1.7 & 1.8 & 1.8 & 1.7 & 1.7 \\
\hline Y & 49 & 46 & 47 & 49 & 50 & 44 & 45.5 \\
\hline $\mathrm{Er}$ & 5.0 & 4.6 & 5.1 & 5.3 & 5.5 & 5.0 & 5 \\
\hline $\mathrm{Tm}$ & 0.70 & 0.64 & 0.72 & 0.75 & 0.77 & 0.70 & 0.7 \\
\hline $\mathrm{Yb}$ & 4.7 & 4.3 & 4.7 & 5.0 & 5.1 & 4.6 & 4.6 \\
\hline $\mathrm{Lu}$ & 0.71 & 0.65 & 0.71 & 0.77 & 0.78 & 0.72 & 0.71 \\
\hline $\mathrm{Ni}$ & 42 & 38 & 37 & 5 & 5 & 6 & 25 \\
\hline $\mathrm{Cu}$ & 303 & 340 & 317 & 231 & 222 & 218 & 330 \\
\hline $\mathrm{Zn}$ & 121 & 131 & 123 & 124 & 121.594 & 109 & 124 \\
\hline
\end{tabular}


Таблица 1. (Окончание)

\begin{tabular}{|c|c|c|c|c|c|c|c|}
\hline Элемент/№№ & $\mathrm{T}-193$ & T-246 & $\mathrm{T}-252$ & $\mathrm{~T}-191$ & $\mathrm{~T}-188$ & $\mathrm{~T}-251$ & $\mathrm{~T}-27$ \\
\hline $\mathrm{Sc}$ & 24 & 24 & 22 & 20 & 22 & 20 & 24 \\
\hline $\mathrm{Co}$ & 31 & 30 & 28 & 18 & 19 & 19 & 26 \\
\hline $\mathrm{Li}$ & 18 & 19 & 17 & 19 & 19 & 18 & 17 \\
\hline V & 309 & 349 & 322 & 250 & 244 & 244 & 335 \\
\hline $\mathrm{W}$ & 0.56 & 0.55 & 0.55 & 0.67 & 0.71 & 0.64 & 0.58 \\
\hline $\mathrm{Be}$ & 1.7 & 1.8 & 1.7 & 1.9 & 1.8 & 1.6 & 1.6 \\
\hline $\mathrm{Cr}$ & 39 & 38 & 36 & - & - & - & 16 \\
\hline $\mathrm{Ga}$ & 22.7 & 21.1 & 23.9 & 23.4 & 23.6 & 23.3 & 24.6 \\
\hline Cs & 2.3 & 2.3 & 2.2 & 2.4 & 2.7 & 2.2 & 2.2 \\
\hline $\mathrm{Sb}$ & 0.52 & 0.47 & 0.43 & 0.62 & 0.65 & 0.53 & 0.45 \\
\hline $\mathrm{Bi}$ & 0.035 & 0.040 & 0.044 & 0.082 & 0.052 & 0.112 & 0.06 \\
\hline As & 1.5 & 0.8 & H.O. & H.O. & H.o. & H.O. & H.o. \\
\hline Mo & 2.3 & 2.2 & 2.3 & 2.6 & 2.7 & 2.5 & 2.3 \\
\hline $\mathrm{Ag}$ & 0.14 & 0.17 & 0.13 & 0.22 & 0.18 & 0.14 & 0.12 \\
\hline $\mathrm{Cd}$ & 0.058 & 0.071 & - & 0.075 & - & - & 0.043 \\
\hline $\mathrm{Tl}$ & 0.08 & 0.09 & 0.10 & 0.18 & 0.37 & 0.26 & 0.07 \\
\hline $\mathrm{Ba} / \mathrm{Nb}$ & 81 & 75 & 62 & 70 & 70 & 65 & 64 \\
\hline $\mathrm{Sr} / \mathrm{Nb}$ & 43 & 44 & 34 & 37 & 37 & 34 & 38 \\
\hline $\mathrm{Rb} / \mathrm{Ba}$ & 0.12 & 0.14 & 0.11 & 0.12 & 0.12 & 0.10 & 0.11 \\
\hline $\mathrm{Ta} / \mathrm{Yb}$ & 0.11 & 0.11 & 0.12 & 0.13 & 0.13 & 0.13 & 0.12 \\
\hline $\mathrm{Nb} / \mathrm{Yb}$ & 1.637 & 1.677 & 1.863 & 1.738 & 1.711 & 1.878 & 1.87 \\
\hline $\mathrm{La} / \mathrm{Yb}$ & 5.2 & 5.1 & 4.9 & 4.8 & 4.6 & 4.8 & 4.9 \\
\hline $87 \mathrm{Sr} / 86 \mathrm{Sr}$ & 0.70336 & 0.70336 & 0.70341 & 0.70339 & 0.70338 & 0.70338 & 0.70337 \\
\hline $143 \mathrm{Nd} / 144 \mathrm{Nd}$ & 0.51310 & 0.51310 & 0.51309 & 0.51309 & 0.51309 & 0.51310 & 0.51310 \\
\hline $206 \mathrm{~Pb} / 204 \mathrm{~Pb}$ & 18.21081 & 18.19537 & 18.18919 & 18.19552 & 18.17651 & 18.18285 & 18.14220 \\
\hline $207 \mathrm{~Pb} / 204 \mathrm{~Pb}$ & 15.50386 & 15.48424 & 15.47554 & 15.48088 & 15.46267 & 15.46621 & 15.41160 \\
\hline $208 \mathrm{~Pb} / 204 \mathrm{~Pb}$ & 37.98343 & 37.91659 & 37.88526 & 37.90351 & 37.84295 & 37.85738 & 37.67360 \\
\hline
\end{tabular}

Примечание. Номера образцов соответствуют таковым на рис.1. Кроме материалов авторов использованы образцы из коллекций Г.Б. Флерова (Т-252) - вулканическая бомба. Окислы образцов Т-193, Т-191, Т-188 из коллекции П. А. Избекова, выполнены в Передовой Инструментальной лаборатории Университета г. Фэрбенкс (Аляска, США). Окислы приведены в вес. \%, элементы-примеси - в г/т.

высокохромистой шпинелью (см. рис. 3). Эти оливины неравновесны к химическим составам пород, в которых они находятся. В то же время, они могут быть равновесны к составам исходных мантийных выплавок [Хубуная и др., 1993, 2007].

\section{ИЗОТОПНЫЕ ХАРАКТЕРИСТИКИ УМЕРЕННОКАЛИЕВЫХ БАЗАЛЬТОВ, АНДЕЗИБАЗАЛЬТОВ \\ И К-ТРАХИАНДЕЗИБАЗАЛЬТОВ КЛЮЧЕВСКОЙ ГРУППЫ ВУЛКАНОВ}

Соотношения радиогенных изотопов являются одной из наиболее важных характеристик ис- точника исходных магм. Они мало меняются в процессе плавления и последующих процессах фракционной кристаллизации в магматической камере [Интерпретация ..., 2001]. Известно, что отношения изотопов $\mathrm{Sr}, \mathrm{Nd}$ и $\mathrm{Pb}$ также позволяют оценивать влияние земной коры на состав магматического расплава. По соотношениям радиогенных изотопов умереннокалиевые базальты и андезибазальты вулканов Ключевской и К-трахиандезибазальты вулкана Плоский Толбачик относятся к мантийным образованиям (рис. 6). Второй важной особенностью всех рассматриваемых вулканитов является отсутствие влияния пород земной коры на исходные умереннокалиевые магнези- 


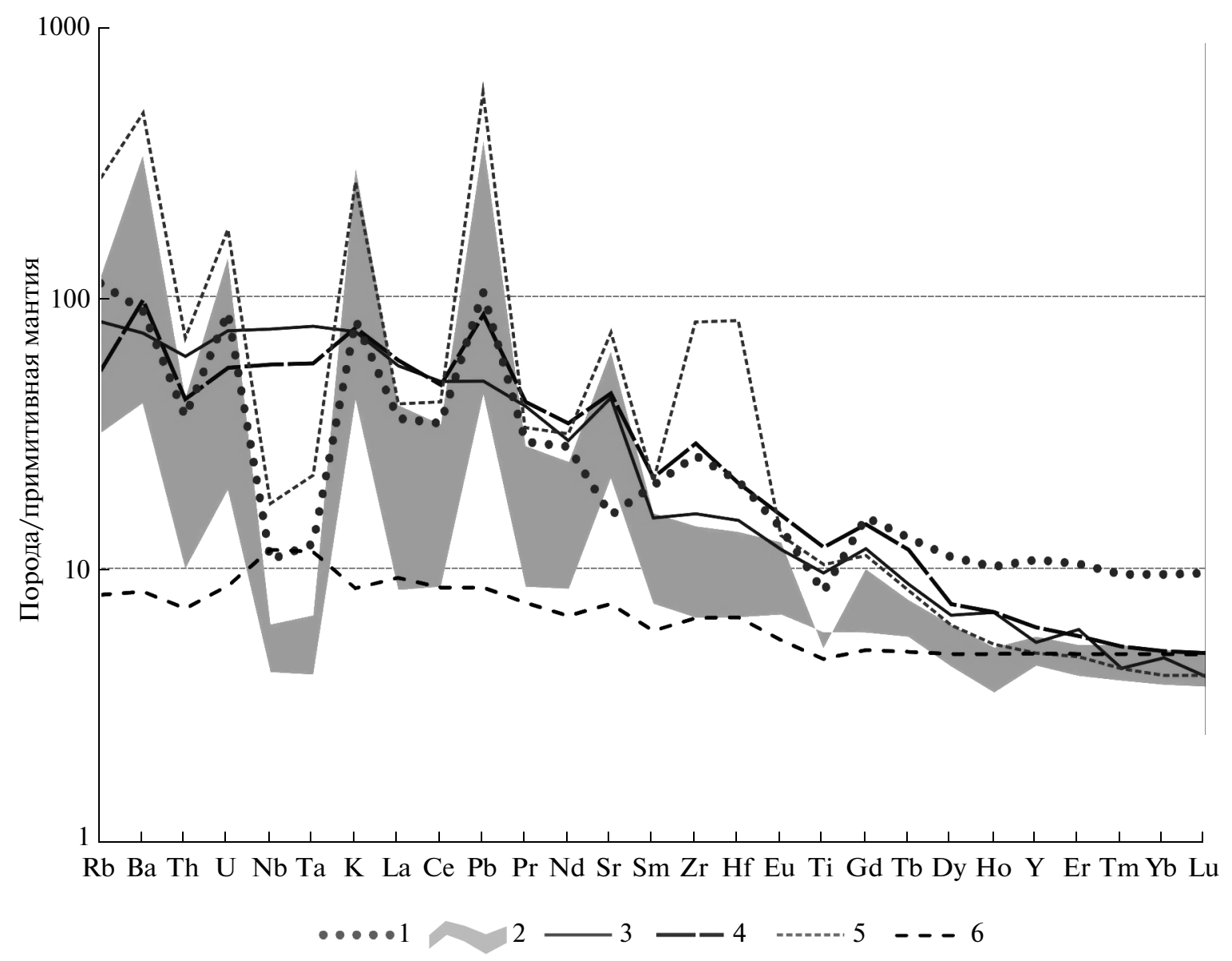

Рис. 5. Спайдердиаграммы рифтогенных и внутриплитных базальтов, базанитов и К-трахиандезибазальтов побочного прорыва 2012-2013 гг. вулкана Плоский Толбачик.

1 - К-трахиандезибазальты побочного прорыва 2012-2013 гг. вулкана Плоский Толбачик; 2 - поле составов шошонитов и латитов Западной Камчатки; 3 - внутриплитные базаниты горы Хухч (Западная Камчатка); 4 - гавайиты Западной Камчатки; 5 - внутриплитные К-щелочные базальты Западной Камчатки; 6 - рифтогенный тренд E-MORB по данным [Sun, McDonough, 1989]. Результаты составов 2, 3, 4, 5 взяты из [Перепелов и др., 2007; Перепелов, 2014]. Содержания элементов-примесей в породах (г/т) нормированы к их концентрациям в недеплетированной мантии по [Sun, McDonough, 1989].

альные, глиноземистые и высококалиевые расплавы (см. рис. 6). Магнезиальные и глиноземистые андезибазальты вулкана Ключевской лежат на линии фракционной кристаллизации. К-трахиандезибазальты, по сравнению с умереннокалиевыми базальтами и андезибазальтами, характеризуются пониженными отношениями радиогенных изотопов ${ }^{87} \mathrm{Sr} / /{ }^{86} \mathrm{Sr},{ }^{143} \mathrm{Nd} /{ }^{144} \mathrm{Nd},{ }^{206} \mathrm{~Pb} /{ }^{204} \mathrm{~Pb}$, при повышенных концентрациях $\mathrm{Rb}$ и $\mathrm{Zr}$ (см. рис. 6).

\section{СРАВНЕНИЕ К-ТРАХИАНДЕЗИБАЗАЛЬТОВ С ВЫСОКОКАЛИЕВЫМИ ОСТРОВОДУЖНЫМИ РИФТОГЕННЫМИ И ВНУТРИПЛИТНЫМИ МАГМАТИЧЕСКИМИ ПОРОДАМИ}

Согласно сравнительной методике нормированного распределения несовместимых элементов по отношениям содержания элемента в поро- де к его концентрации в примитивной мантии, на Камчатском полуострове были выделены высококалиевые надсубдукционные (островодужные) и K-Na внутриплитные базанитовые и калиевые трахибазальтовые серии разного возраста (см. рис. 5), характеризующиеся ярко выраженными геохимическими и минералогическими особенностями [Волынец, 1993; Волынец и др., 1990, 1995, 1997; Колосков и др., 2011; Перепелов, 1989, 2014; Перепелов и др., Препелов; др.,7ивной мантии 2003, 2005, 2006, 2007].

По высокому содержанию $\mathrm{Rb}$, одного из наиболее несовместимых легких литофильных элементов К-трахиандезибазальты близки внутриплитным поздненеогеновым K-Na щелочным базальтоидам Восточной Камчатки, которые были выделены рядом исследователей [Волынец и др., 1990, 1997; Перепелов и др., 2006, 2007; и др.]. В то 
Таблица 2. Представительные составы умереннокалиевых магнезиальных и глиноземистых базальтов и андезибазальтов вулканов Ключевской группы и вулкана Харчинский

\begin{tabular}{|c|c|c|c|c|c|c|}
\hline Окислы/№№ & $11-3$ & $32-810 / 35$ & $57-826-77$ & $1-\mathrm{KL}$ & 974 ГФ & $2023-103$ \\
\hline $\mathrm{SiO}_{2}$ & 51.98 & 52.90 & 54.11 & 54.13 & 54.33 & 52.77 \\
\hline $\mathrm{TiO}_{2}$ & 0.78 & 0.89 & 0.95 & 1.12 & 0.83 & 0.86 \\
\hline $\mathrm{Al}_{2} \mathrm{O}_{3}$ & 13.64 & 16.40 & 16.96 & 18.17 & 21.62 & 14.29 \\
\hline $\mathrm{FeO}$ & 8.47 & 8.24 & 8.32 & 8.58 & 8.67 & 8.60 \\
\hline $\mathrm{MnO}$ & 0.17 & 0.17 & 0.18 & 0.15 & 0.12 & 0.17 \\
\hline $\mathrm{MgO}$ & 11.00 & 7.54 & 5.82 & 4.51 & 2.04 & 9.90 \\
\hline $\mathrm{CaO}$ & 10.04 & 9.49 & 8.87 & 8.16 & 8.95 & 9.45 \\
\hline $\mathrm{Na}_{2} \mathrm{O}$ & 2.29 & 2.86 & 3.03 & 3.52 & 3.80 & 2.81 \\
\hline $\mathrm{K}_{2} \mathrm{O}$ & 0.59 & 0.64 & 0.92 & 1.05 & 1.15 & 0.97 \\
\hline $\mathrm{P}_{2} \mathrm{O}_{5}$ & 0.16 & 0.13 & 0.17 & 0.13 & 0.22 & 0.18 \\
\hline Сумма & 99.13 & 99.24 & 99.33 & 99.51 & 101.72 & 99.96 \\
\hline $\mathrm{Rb}$ & 9 & 10 & 15 & 16 & 14 & 15 \\
\hline $\mathrm{Ba}$ & 227 & 237 & 358 & 423 & 296 & 360 \\
\hline Th & 0.5 & 0.5 & 0.8 & 0.8 & 0.7 & 0.7 \\
\hline $\mathrm{U}$ & 0.3 & 0.3 & 0.4 & 0.4 & 0.5 & 0.4 \\
\hline $\mathrm{Nb}$ & 1.3 & 1.5 & 1.9 & 2.1 & 2.5 & 1.5 \\
\hline $\mathrm{Ta}$ & 0.09 & 0.11 & 0.13 & 0.14 & 0.16 & 0.10 \\
\hline K & 4899 & 5313 & 7637 & 8716 & 9547 & 8052 \\
\hline $\mathrm{La}$ & 4.5 & 5.2 & 6.9 & 7.7 & 6.4 & 6.6 \\
\hline $\mathrm{Ce}$ & 10.8 & 12.2 & 16.0 & 17.3 & 16.2 & 15.5 \\
\hline $\mathrm{Pb}$ & 1.9 & 2.1 & 2.8 & 3.5 & 3.3 & 4.1 \\
\hline $\operatorname{Pr}$ & 1.7 & 2.0 & 2.5 & 2.7 & 2.5 & 2.4 \\
\hline $\mathrm{Nd}$ & 9.3 & 10.6 & 12.7 & 13.6 & 11.8 & 12.0 \\
\hline $\mathrm{Sr}$ & 239 & 301 & 358 & 367 & 418 & 432 \\
\hline $\mathrm{Sm}$ & 2.7 & 3.1 & 3.5 & 3.7 & 3.2 & 3.1 \\
\hline $\mathrm{Zr}$ & 69 & 82 & 91 & 95 & 89 & 72 \\
\hline $\mathrm{Hf}$ & 1.8 & 2.1 & 2.4 & 2.5 & 2.4 & 2.0 \\
\hline $\mathrm{Eu}$ & 0.87 & 1.01 & 1.15 & 1.33 & 1.13 & 1.1 \\
\hline $\mathrm{Ti}$ & 4675 & 5335 & 5694 & 6713 & 4975 & 5155 \\
\hline Gd & 2.9 & 3.3 & 3.6 & 4.0 & 3.5 & 3.1 \\
\hline $\mathrm{Tb}$ & 0.5 & 0.6 & 0.6 & 0.6 & 0.5 & 0.5 \\
\hline Dy & 3.4 & 3.9 & 4.1 & 4.5 & 3.3 & 3.1 \\
\hline Ho & 0.7 & 0.8 & 0.9 & 0.9 & 0.7 & 0.6 \\
\hline $\mathrm{Y}$ & 18 & 19 & 20 & 23 & 17 & 15 \\
\hline $\mathrm{Er}$ & 2.1 & 2.3 & 2.5 & 2.5 & 2.1 & 1.6 \\
\hline $\mathrm{Tm}$ & 0.29 & 0.33 & 0.36 & 0.34 & 0.28 & 0.23 \\
\hline $\mathrm{Yb}$ & 2.0 & 2.4 & 2.6 & 2.3 & 1.9 & 1.57 \\
\hline $\mathrm{Lu}$ & 0.30 & 0.34 & 0.38 & 0.37 & 0.29 & 0.22 \\
\hline $\mathrm{Ni}$ & 184 & 86 & 38 & 24 & 19 & 152 \\
\hline $\mathrm{Cu}$ & 71 & 70 & 92 & 101 & 112 & 107 \\
\hline $\mathrm{Zn}$ & 79 & 118 & 80 & 90 & 88 & 177 \\
\hline
\end{tabular}


Таблица 2. (Окончание)

\begin{tabular}{|c|c|c|c|c|c|c|}
\hline Окислы/№№ & $11-3$ & $32-810 / 35$ & $57-826-77$ & $1-\mathrm{KL}$ & 974 ГФ & $2023-103$ \\
\hline $\mathrm{Sc}$ & 42 & 36 & 34 & 29 & 15 & 33 \\
\hline $\mathrm{Co}$ & 43 & 33 & 29 & 29 & 18 & 44 \\
\hline $\mathrm{Li}$ & 7 & 8 & 12 & 32 & 8 & 8 \\
\hline $\mathrm{V}$ & 242 & 231 & 267 & 265 & 199 & 237 \\
\hline W & 0.07 & 0.10 & 0.13 & 0.18 & 0.36 & 0.22 \\
\hline $\mathrm{Ba} / \mathrm{Nb}$ & 173 & 155 & 189 & 206 & 120 & 240 \\
\hline $\mathrm{Sr} / \mathrm{Nb}$ & 182 & 196 & 189 & 178 & 170 & 288 \\
\hline $\mathrm{Rb} / \mathrm{Ba}$ & 0.04 & 0.04 & 0.04 & 0.04 & 0.05 & 0.04 \\
\hline $\mathrm{Ta} / \mathrm{Yb}$ & 0.044 & 0.045 & 0.050 & 0.062 & 0.085 & 0.064 \\
\hline $\mathrm{Nb} / \mathrm{Yb}$ & 0.644 & 0.651 & 0.740 & 0.887 & 1.287 & 0.955 \\
\hline $\mathrm{La} / \mathrm{Yb}$ & 2.2 & 2.2 & 2.7 & 3.3 & 3.4 & 4.2 \\
\hline $87 \mathrm{Sr} / 86 \mathrm{Sr}$ & 0.70369 & 0.703589 & 0.70353 & 0.703664 & 0.70351 & 0.70352 \\
\hline $143 \mathrm{Nd} / 144 \mathrm{Nd}$ & 0.51282 & 0.513156 & 0.51316 & 0.513097 & 0.51309 & 0.51311 \\
\hline $206 \mathrm{~Pb} / 204 \mathrm{~Pb}$ & 18.30000 & 18.30100 & 18.2947 & 18.30690 & 18.23098 & 18.22710 \\
\hline $207 \mathrm{~Pb} / 204 \mathrm{~Pb}$ & 15.52200 & 15.54500 & 15.4958 & 15.48892 & 15.48169 & 15.45980 \\
\hline $208 \mathrm{~Pb} / 204 \mathrm{~Pb}$ & 38.04500 & 38.09200 & 37.9756 & 37.96904 & 37.92443 & 37.80310 \\
\hline
\end{tabular}

Примечание. Вулкан Ключевской: № 11-3 - магнезиальный базальт из лавового потока конуса б/н; № 32-810/35 - магнезиальный андезибазальт из вулканической бомбы эксплозивного конуса Е; № 57-826-77 - глиноземистый андезибазальт из лавового потока Невидимка; № 1-KL - глиноземистый андезибазальт из лавового потока вершинного извержения 2008 г. № 974 ГФ - глиноземистый андезибазальт из лавового потока геологического разреза вулкана Плоский Толбачик. № 2023-103 магнезиальный андезибазальт из лавового потока из геологического разреза вулкана Харчинский. Названия лавовых потоков и конусов вулкана Ключевской соответствуют [Ермаков, 1977].

же время, К-трахиандезибазальты резко отличаются от K-Na щелочных и субщелочных вулканитов Nb-, Та-, Се-минимумами и повышенными концентрациями тяжелых РЗЭ (см. рис. 6). Кроме того, внутриплитные К-Na щелочные базальтоиды Восточной Камчатки характеризуются более высокими значениями величин ${ }^{87} \mathrm{Sr} /{ }^{86} \mathrm{Sr}$ по сравнению с лавами островодужных типов [Волынец и др., 1997]. Рассматриваемые К-трахиандезибазальты характеризуются более низкими отношениями ${ }^{87} \mathrm{Sr} /{ }^{86} \mathrm{Sr}$, чем лавы островодужных типов и более низкими значениями этого параметра, в отличие от поздненеогеновых $\mathrm{K}-\mathrm{Na}$ щелочных базальтоидов Восточной Камчатки (см. рис. 6).

K-трахиандезибазальты на мультикомпонентных диаграммах по высоким содержаниям U, a также Th-, Nb-Ta-, La-Ce- и Ti-минимумами близки внутриплитным позднеэоцен-раннеолигоценовым К-щелочным базальтоидам Западной Камчатки. К-щелочные базальтоиды Западной Камчатки отличаются от рассматриваемых К-трахиандезибазальтов на спайдердиаграммах высокой степенью дифференциации, аномально высокими содержаниями $\mathrm{K}, \mathrm{Pb}, \mathrm{Zr}$, Hf, резким дефицитом $\mathrm{Rb}$ по отношению к $\mathrm{Ba}$, Sr-максимумами и пониженными содержаниями тяжелых РЗЭ (см. рис. 5). По этим геохимическим параметрам на спайдердиаграммах их фигуративные точки практически совпадают с таковыми ранне-позднемиоценового шошонит-латитового магматизма Западной Камчатки. В то же время шошониты, в отличие от К-трахиандезибазальтов, характеризуются аномально низкими $\mathrm{Nb}-\mathrm{Ta}-, \mathrm{La}-\mathrm{Ce}-, \mathrm{Pr}-$ $\mathrm{Nd}$-минимумами и пониженными содержаниями 

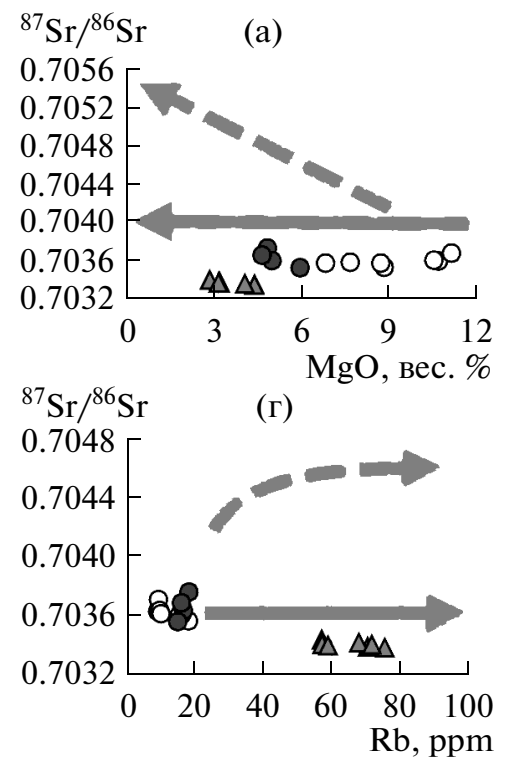

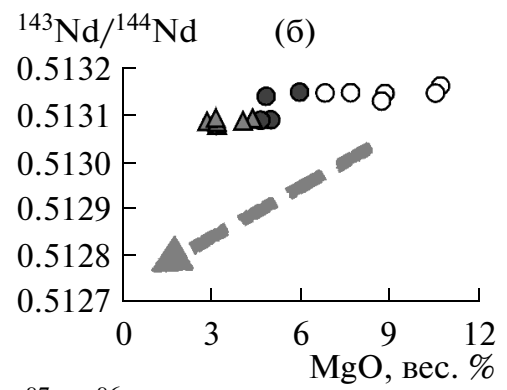

${ }^{87} \mathrm{Sr} /{ }^{86} \mathrm{Sr}$

0.7048

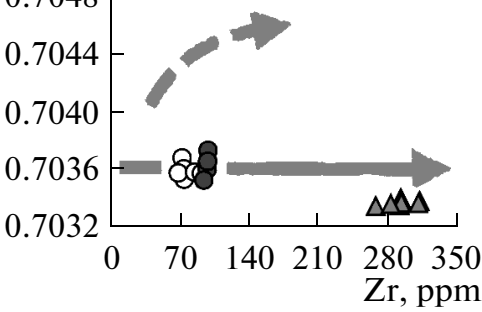

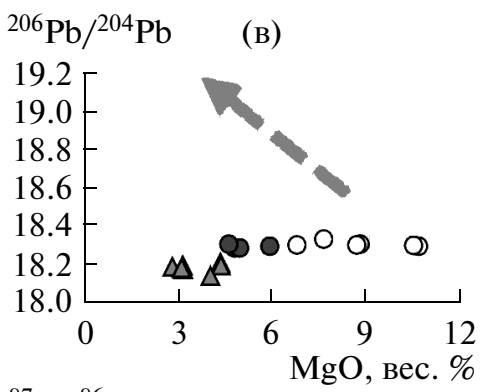

(e)

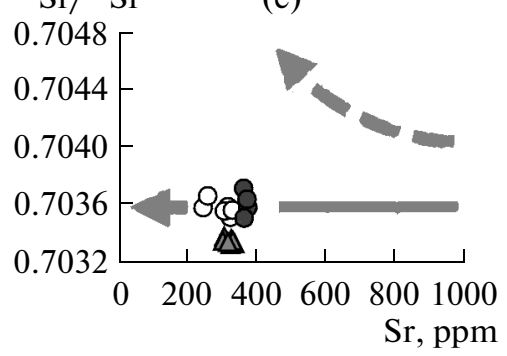

01
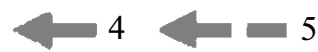

Рис. 6. Изотопные характеристики представительных образцов базальтов и андезибазальтов района Ключевской группы вулканов.

Вулкан Ключевской: 1 - магнезиальные базальты и андезибазальты, 2 - глиноземистые андезибазальты, 3 - К-трахиандезибазальты, вулкан Плоский Толбачик, 4 - линии фракционной кристаллизации; 5 (а, б, в) - линия коровой ассимиляции, Малая Антильская дуга; 5 (г, д, е) - линия коровой ассимиляции, вулкан Салина. Обозначения 4 и 5 взяты из [Альмеев, 2005].

Sm, Zr, Hf. Кроме того, К-щелочные базальтоиды обладают высокой магнезиальностью, высокими содержаниями $\mathrm{Ni}, \mathrm{Cr}$, Co. Для них характерно присутствие высокохромистой шпинели, $\mathrm{Cr}$-диопсида и $\mathrm{Cr}$-содержащего флогопита [Волынец и др., 1997; Перепелов, 2014; и др.].

К-трахиандезибазальты на мультикомпонентных диаграммах резко отличаются от внутриплитных базанитов Западной Камчатки и гавайитов Срединного хребта Камчатки $\mathrm{Nb}-\mathrm{Ta}-$ и $\mathrm{Sr}-$ минимумами, $\mathrm{Pb}$-максимумами, преобладанием содержаний $\mathrm{Rb}$ над Ва и существенным преобладанием тяжелых РЗЭ (см. рис. 5). Кроме того, значения многих маркирующих редкоэлементных отношений в базанитах и ВК-трахиандезибазальтах сильно отличаются. В базанитах отношения $\mathrm{Ba} / \mathrm{Nb}$ в 6-8 раз меньше, a $\mathrm{Ta} / \mathrm{Yb}$ на порядок больше, чем в BK-трахиандезибазальтах; $\mathrm{Ba} / \mathrm{Nb}=$ $=10-12$ и $60-80, \mathrm{Ta} / \mathrm{Yb}=1.3-1.6$ и $0.11-0.13$, соответственно (см. табл. 1). Для базанитов характерны высокие концентрации сидерофильных элементов (Co, $\mathrm{Ni}, \mathrm{Cr})$, высокозарядных элементов ( $\mathrm{Nb}, \mathrm{Ta})$, радиоактивных (U), на фоне умеренных содержаний $\mathrm{Zr}, \mathrm{Hf}, \mathrm{Pb}, \mathrm{Cu}$ и Sn [Перепелов, 2014].

Наиболее близкие к К-трахиандезибазальтам по кремнекислотности и $\mathrm{K}_{2} \mathrm{O}$ высококалиевые андезибазальты вулкана Уксичан характеризуются резким дефицитом Rb (28 г/т) по отношению K
Ва (850 г/т). В мегаплагиофировых шошонит-латитовых базальтах вулкана Теклетунуп (Срединный хребет) и шошонитовых базальтах Западной Камчатки это отношение еще ниже - Rb (46 и 88 г/т) и $\mathrm{Ba}(1520$ и 1100 г/т), соответственно [Перепелов, 1989, табл. 1]. На спайдердиаграммах Ктрахиандезибазальтов, наоборот, фиксируется дефицит Ва по отношению к Rb. Кроме того, содержание $\mathrm{TiO}_{2}$ во всех высококалиевых базальтах и андезибазальтах вулкана Уксичан и вулкана Теклетунуп в 2 раза ниже, чем в К-трахиандезибазальтах $(0.89 \%, 1 \%$ и $2 \%$, соответственно).

Проведенный сравнительный анализ нормированного распределения содержаний несовместимых элементов К-трахиандезибазальтов и внутриплитных пород по отношению их концентраций к таковым в примитивной мантии показал, что они имеют различные источники. К-трахиандезибазальты не относятся ни к одной из выделенных разновозрастных внутриплитных высококалиевых или $\mathrm{K}-\mathrm{Na}$ серий Камчатского полуострова. В то же время, они извергались в голоцене в непосредственной близости от надсубдукционных умереннокалиевых базальтов и андезибазальтов вулканов Ключевской, Плоский Толбачик (извержения 1941 г.), Толбачинского дола (Северный прорыв БТТИ, 1975 г.). Сравнение геохимических особенностей К-трахиандезибазальтов с таковыми надсубдукционных 


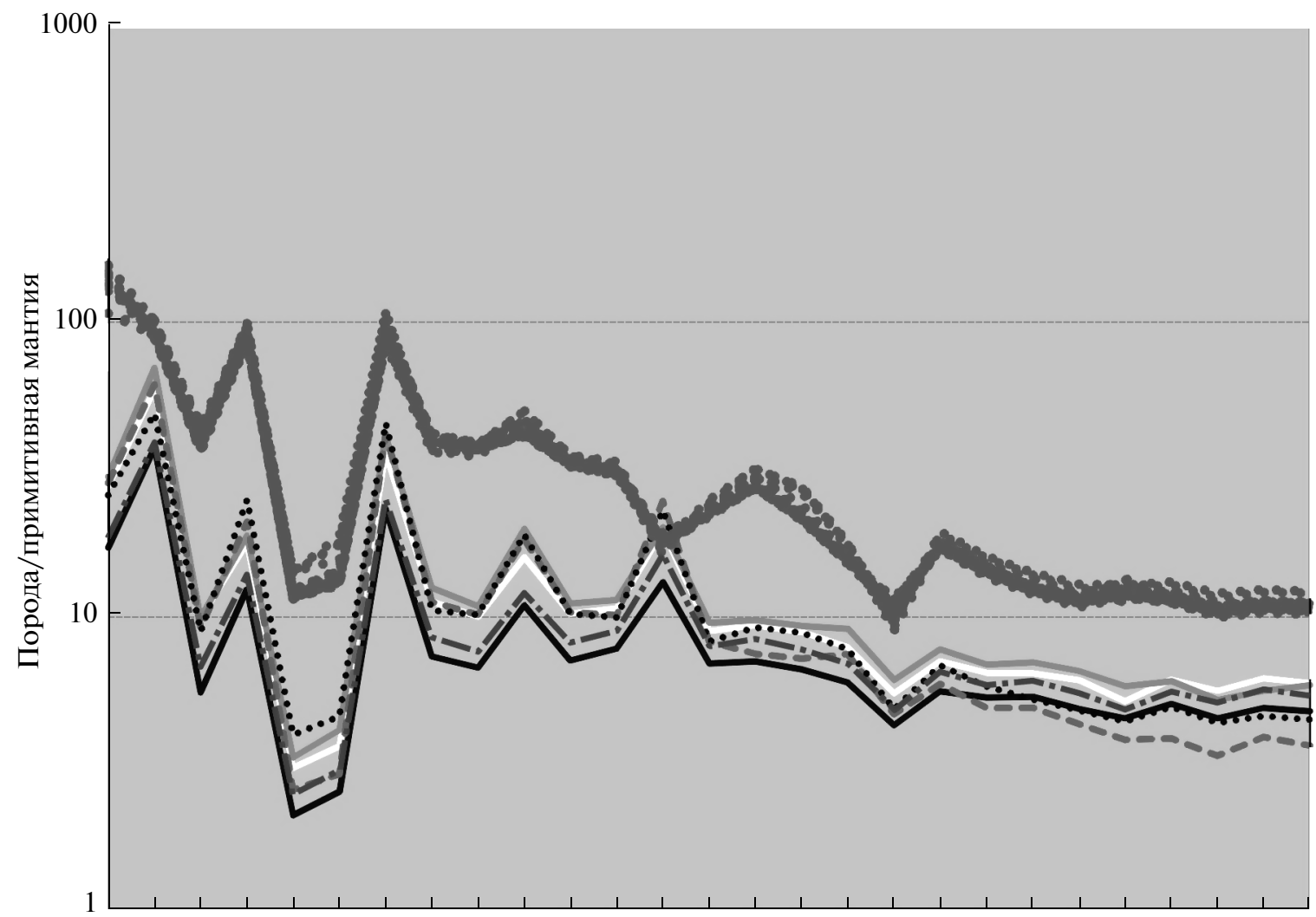

Rb Ba Th U Nb Ta K La Ce Pb Pr Nd Sr Sm Zr Hf Eu Ti Gd Tb Dy Ho Y Er Tm Yb Lu

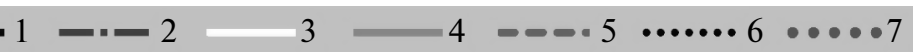

Рис. 7. Спайдердиаграммы К-трахиандезибазальтов, умереннокалиевых базальтов и андезибазальтов.

Вулкан Ключевской: 1 - магнезиальный базальт лавового потока конуса б/н ( № 11-3); 2 - магнезиальный андезибазальт вулканической бомбы эксплозивного конуса Е (32-810/35); 3 - глиноземистый андезибазальт из лавового потока Невидимка (№ 57-826-76); 4 - глиноземистый андезибазальт из лавового потока вершинного извержения 2008 г. (№ 1-KL); 5 - магнезиальный андезибазальт из лавового потока геологического разреза вулкана Харчинский (2023-104).

Вулкан Плоский Толбачик: 6 - глиноземистый андезибазальт из лавового потока из геологического разреза вулкана (974 ГФ); 7 - К-трахиандезибазальты побочного прорыва 2012-2013 гг. Содержания элементов-примесей в породах (г/т) нормированы к их концентрациям в примитивной мантии по [Hoffman, 1988]. Названия конусов вулкана Ключевской соответствуют таковым [Ермаков, 1977].

умереннокалиевых базальтов и андезибазальтов Ключевской группы вулканов может помочь выяснению их формационной принадлежности.

\section{СРАВНЕНИЕ К-ТРАХИАНДЕЗИБАЗАЛЬТОВ С НАДСУБДУКЦИОННЫМИ УМЕРЕННОКАЛИЕВЫМИ БАЗАЛЬТАМИ И АНДЕЗИБАЗАЛЬТАМИ}

Все известково-щелочные умереннокалиевые магнезиальные и глиноземистые базальты и андезибазальты Ключевской группы вулканов на многокомпонентой диаграмме распределения несовместимых элементов характеризуются близкой конфигурацией точек всех элементов-примесей (рис. 7). На спайдердиаграммах они обладают глубокими минимумами высокозарядных эле- ментов (Th, $\mathrm{Nb}, \mathrm{Ti})$ и максимумами крупноионных литофильных элементов ( $\mathrm{Ba}, \mathrm{K}, \mathrm{Sr}, \mathrm{Pb})$, а также U. Такое распределение элементов-примесей характерно для пород надсубдукционных умереннокалиевых серий Камчатки. Ярко выраженный $\mathrm{Sr}$-максимум наблюдается для всех умереннокалиевых пород - как для наиболее высокомагнезиальных и глиноземистых базальтов и андезибазальтов вулкана Ключевской, так и для наиболее глиноземистых андезибазальтов вулкана Плоский Толбачик (см. рис. 7). Подобное распределение $\mathrm{Sr}$ характерно и для всех островодужных вулканических пород [Holm, 1985; Волынец и др., 1999; и др.]. Такая типичная геохимия умереннокалиевых островодужных магм, в рамках теории мобилизма, традиционно описывается как смешение двух независимых компонентов, характе- 
ризующих источники этих магм: сильно обедненного “сухого" вещества (мантийный клин под островной дугой над зоной субдукции) и компонента, являющегося либо выплавкой островодужной мантии, либо продуктом дегидратации субдукционной плиты. В результате этого процесса в магму может привноситься основная доля элементов с крупными радиусами ионов и воды [Pearce et al., 2005]. Об этом же свидетельствуют экспериментальные данные [Tatsumi et al., 1994]. Геохимия изученных умереннокалиевых вулканитов в общем виде не противоречит подобной модели. Фиксируется явная диспропорция в соотношении $\mathrm{Rb}$ и $\mathrm{Ba}$, дефицит $\mathrm{Rb}$ по отношению к Ba, который наблюдается на спайдердиаграммах всех умереннокалиевых островодужных базальтов (см. рис. 7). Это обстоятельство позволяет предполагать, что в мантийном остатке должна быть фаза, содержащая Rb, по-видимому, флогопит [Хубуная, Соболев, 1998]. Для генезиса исходных расплавов умереннокалиевых магнезиальных базальтов Ключевского вулкана предложена модель плавления недеплетированного мантийного источника лерцолит-гарцбургитового ряда под воздействием водосодержащего компонента поддвигающейся плиты [Хубуная, Соболев, 1998]. Полученные результаты позволяют предполагать, что расплав отделился от мантийного вещества на глубинах 50-60 км [Хубуная и др., 2007].

Сходство геохимических и минералогических особенностей умереннокалиевых магнезиальных базальтов вулканов Ключевской, Плоский Толбачик (извержение 1941 г.), Толбачинского дола (Cеверный прорыв БТТИ) позволяют предполагать для них один и тот же мантийный источник. Этому положению не противоречат результаты последних геофизических исследований. Возможность перемещения исходных умереннокалиевых магнезиальных расплавов на значительные расстояния (до 100 км) из одного периферического очага под вулканом Ключевской [Федотов и др., 2014] может объяснить современные извержения умереннокалиевых магнезиальных базальтов под вулканом Плоский Толбачик и на Толбачинском долу. В то же время, с умереннокалиевыми высокомагнезиальными базальтами и их дифференциатами было проведено расчетное моделирование методом наименьших квадратов [Wright, Doherti, 1970]. Оно показало, что в результате фракционной кристаллизации O1 и Срх из исходного умереннокалиевого высокомагнезиального базальтового расплава можно получить умереннокалиевый магнезиальный базальт [Хубуная и др., 1993]. К-трахиандезибазальты не могут быть получены в результате фракционной кристаллизации, из исходных умереннокалиевых высокомагнезиальных расплавов. Они должны иметь свой независимый источник.

\section{ФОРМАЦИОННАЯ ПРИНАДЛЕЖНОСТЬ К-ТРАХИАНДЕЗИБАЗАЛЬТОВ}

Рассмотренные геохимические особенности К-трахиандезибазальтов позволяют предполагать, что их источник наиболее близок мантийному надсубдукционному источнику островодужных умереннокалиевых базальтовых серий. На это указывает, прежде всего, близкое сходство графиков фигуративных точек на спайдердиаграмме (см. рис. 7). Также как и умереннокалиевые базальтоиды Ключевской группы вулканов и вулкана Харчинский, К-трахиандезибазальты на спайдердиаграммах характеризуются типичными геохимическими признаками надсубдукционных умереннокалиевых магм: отчетливыми минимумами высокозарядных элементов $\mathrm{Ti}, \mathrm{Nb}, \mathrm{Ta}, \mathrm{Th}$ и $\mathrm{Ce}$, отчетливыми U-, K-, Рb-максимумами. Графики фигуративных точек тяжелых РЗЭ К-трахиандезибазальтов и умереннокалиевых базальтов и андезибазальтов, от Gd до Lu, располагаются параллельно. Все это свидетельствует о близости составов мантийных источников сравниваемых пород.

Основными отличиями в распределении несовместимых элементов на спайдердиаграммах умереннокалиевых базальтоидов и К-трахиандезибазальтов являются Rb-максимумы, Sr-минимумы и повышенные содержания всех несовместимых элементов в последних (см. рис. 7). Формационный геохимический анализ основан на отношениях средних концентраций несовместимых элементов в породе к содержанию этих элементов в примитивной мантии (нормированные отношения) [Wood, 1979]. Петрографический, минералогический и геохимический анализ K-трахиандезибазальтов позволяет с большей достоверностью оценивать их формационную принадлежность. Одним из важных химических элементов в подобном формационном анализе является Sr [Holm, 1985; Волынец и др., 1995; и др.]. Известно, что основным концентратором $\mathrm{Sr}$ магматическом процессе является плагиоклаз. Коэффициенты распределения между Sr и плагиоклазом очень высоки. В основных расплавах они соответствуют 2.2, а для средних и кислых - 4.4 [Кокс и др., 1982, с. 308]. Известно, что плагиоклаз подвержен процессам кристаллизационно-гравитационной дифференциации в промежуточных магматических очагах. Это нельзя не учитывать при отнесении К-трахиандезибазальтов к той или иной геохимической формации, основанной, в том числе, и на концентрации в них Sr. Изотопные характеристики $\mathrm{Pb}, \mathrm{Nd}, \mathrm{Sr}$ K-трахиандезибазальтов свидетельствуют об их мантийном генезисе. Это - низкомагнезиальные вулканические породы (см. табл. 1). Составы фенокристаллов наиболее магнезиальных оливинов $\left(\mathrm{Fo}_{83-72}\right)$ не соответ- 
ствуют тем, которые могут быть равновесны мантийным выплавкам $\mathrm{Fo}_{89-92}$ [Lee Cin-Ty et al., 2009]. По существу, К-трахиандезибазальты - глубоко дифференцированные субафировые вулканические образования. Их петрографические, минералогические и геохимические особенности позволяют предполагать значительную фракционную кристаллизацию плагиоклаза в малоглубинной (1-2 км) камере под вулканом Плоский Толбачик. Расположение промежуточной магматической камеры основано на результатах сейсмологических исследований [Ермаков и др., 2014]. Фракционная кристаллизация плагиоклаза могла происходить за счет дегазации воды при низких давлениях в малоглубинной промежуточной камере, либо за счет менышего исходного содержания воды в расплаве К-трахиандезибазальтов, по сравнению с содержанием воды (3-3.5\%) в исходных расплавах умереннокалиевых магнезиальных базальтов [Хубуная, Соболев, 1998; Миронов, Портнягин, 2011; и др.]. Крупные фенокристаллы плагиоклаза, сростки плагиоклазов могли аккумулироваться на дне малоглубинной магматической камеры и образовывать плагиоклазовые кумулаты (см. рис. 2д, 2е). При этом остаточный расплав в апикальной части магматической камеры мог обедняться Sr. На возможность отсадки Pl указывают $\mathrm{Sr}$-минимумы на спайдердиаграммах $\mathrm{K}$ трахиандезибазальтов, неравномерное распределение крупных фенокристаллов плагиоклаза в поднимающейся магме (см. рис. 2б). Апикальная часть малоглубинного промежуточного очага была обеднена кристаллами плагиоклаза. На возможность отсадки плагиоклаза указывают крупные кристаллолапилли (пластинки и сростки плагиоклазов), которые извергалось вместе со шлаковыми лапилли К-трахиандезибазальтов (см. рис. 2б, 2в, 2г). Об этом же могут свидетельствовать и кумулаты плагиоклаза (см. рис. 2д, 2е). Эти кумулятивные образования плагиоклаза встречаются в виде ксенолитов в вулканических бомбах при извержениях Северного прорыва БТТИ, извержениях прорыва Лавовый Шиш, вулкана Плоская Дальняя и других районах, где извергались К-трахиандезибазальты или мегаплагиофировые базальты (рис. 2д, 2е). Ксенолиты плагиоклазовых кумулатов отсутствуют при извержениях вулканов Ключевской, Безымянный, Шивелуч там, где не было извержений K-трахиандезибазальтов или мегаплагиофировых базальтов. Исходя из вышеизложенного, можно предположить, что исходный высокоглиноземистый расплав $\mathrm{K}$-трахиандезибазальтов был обогащен $\mathrm{Sr}$ и на спайдердиаграммах мог иметь Sr-максимум, как и все надсубдукционные базальты и андезибазальты.

Одной из главных геохимических особенностей К-трахиандезибазальтов являются высокие содержания Rb. На спайдердиаграмме этих пород

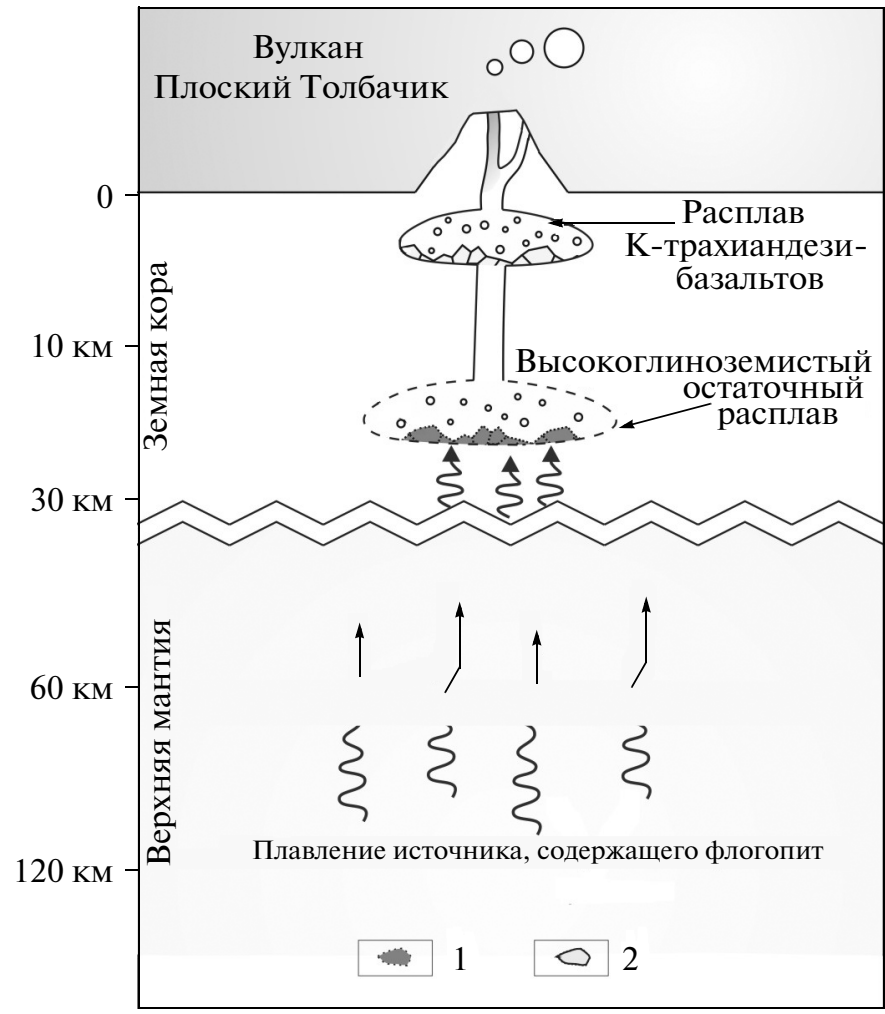

Рис. 8. Предполагаемая модель формирования К-трахиандезибазальтов побочного извержения 2012-2013 гг. вулкана Плоский Толбачик (ТТИ-50).

1 - высокомагнезиальные оливины и клинопироксены; 2 - плагиоклазовые кумулаты.

фиксируется Rb-максимум. Повышенные содержания Rb в K-трахиандезибазальтах, высокие отношения $\mathrm{Rb} / \mathrm{Ba}$, почти на порядок превышающие таковые в умереннокалиевых породах, свидетельствуют, что в плавящемся мантийном субстрате должна быть фаза, содержащая $\mathrm{Rb}$, по-видимому, флогопит (см. табл. 1, 2). Известно, что флогопит, в отсутствии амфибола, наиболее вероятный накопитель не только $\mathrm{Rb}$, но К и $\mathrm{H}_{2} \mathrm{O}$ [Кокс и др., 1982]. Вероятно, полное разложение флогопита флюидами, при дегидратации субдукционной плиты, привело к плавлению глубинного надсубдукционного источника К-трахиандезибазальтов. При этом он был более глубинный, чем источник умереннокалиевых пород [Хубуная Соболев, 1998; Хубуная и др., 2007]. Известно, что устойчивость флогопита в верхней мантии сохраняется до давлений 35 кбар [Bravo, O Hara, 1975]. К тому же мантийный источник К-трахиандезибазальтов, вероятно, претерпел меньшую степень парциального плавления, чем источник умереннокалиевых пород. Отношения $\mathrm{Nb} / \mathrm{Yb}$ в K-трахиандезибазальтах в 2 раза выше, чем в умереннокалиевых базальтах и андезибазальтах (см. табл. 1, 2). 
Повышенные содержания всех несовместимых элементов в К- трахиандезибазальтах, по сравнению с умереннокалиевыми породами, вероятно, связаны со значительной фракционной кристаллизацией плагиоклаза в расплаве малоглубинной магматической камеры. Более высокие содержания несовместимых элементов в К-трахиандезибазальтах, по-видимому, также связаны с обогащением их исходных расплавов флюидами, содержащими несовместимые элементы, при дегидратации субдукционной плиты [Tatsumi et al., 1994].

Извержение К-трахиандезибазальтов на южном склоне вулкана Плоский Толбачик, описанные распределения несовместимых элементов в последних, могут быть связаны с плавлением надсубдукционного мантийного источника, более глубинного, чем источник умереннокалиевых пород. Вероятно, этот источник претерпел меньшую степень плавления. Глубина плавления источника K-трахиандезибазальтов ограничена глубиной разложения флогопита. В работах [Хубуная, Соболев, 1998; Хубуная и др., 2007], показано, что плавление источника надсубдукционных умереннокалиевых магнезиальных базальтов происходит на глубинах 50-60 км. Более глубокое (до 100-110 км) плавление источника К-трахиандезибазальтов свидетельствует о гетерогенности мантии и разных уровнях плавления мантийных источников сравниваемых пород.

\section{ПРЕДПОЛАГАЕМАЯ СХЕМА ОБРАЗОВАНИЯ К-ТРАХИАНДЕЗИБАЗАЛЬТОВ}

Петрографические, минералогические и геохимические особенности К-трахиандезибазальтов позволяют предполагать двухэтапную фракционную кристаллизацию исходного родоначального расплава в промежуточных магматических камерах под вулканом Плоский Толбачик (рис. 8). На первом этапе в промежуточной магматической камере на глубине 15-20 км [Ермаков и др., 2014] из магнезиального расплава в присутствии $\mathrm{H}_{2} \mathrm{O}$ могли кристаллизоваться высокомагнезиальные оливины и пироксены. При этом поле кристаллизации плагиоклаза значительно сужалось. Остаточный расплав обогащался глиноземом, щелочами и обеднялся магнием и железом. На возможность подобной кристаллизации базальтового расплава в присутствии воды в экспериментальных работах показали Д. Грин и А. Рингвуд [Green, Ringwood, 1968]. K сожалению, отсутствуют данные по составам высокомагнезиальных минералов, которые могли кристаллизоваться на первом этапе, в глубинной магматической камере (см. рис. 8). В то же время, 26 несовместимых элементов, определенных в К-трахиандезибазальтах, характеризуют не только их геохимические особенности, но и геохимические особенности их исходных (первичных) расплавов. Несовместимые элементы в рассмотренном магматическом процессе не имеют минералов концентраторов (кроме плагиоклаза) и дальнейшие процессы фракционной кристаллизации в глубинном промежуточном очаге почти не влияли на изменение концентрации несовместимых элементов в расплаве.

Дальнейшая фракционная кристаллизация плагиоклаза из остаточного высокоглиноземистого расплава могла происходить на глубине 1-2 км в малоглубинной камере (см. рис. 8). Остаточный расплав в апикальной части малоглубинной промежуточной магматической камеры обеднялся плагиоклазом. Прямо на это указывают $\mathrm{Sr}$-минимумы на спайдердиаграммах $\mathrm{K}$-трахиандезибазальтов. Об этом же свидетельствуют процессы фракционной кристаллизации плагиоклаза в малоглубинном промежуточном очаге, описанные выше.

Рассмотренные геохимические особенности К-трахиандезибазальтов позволяют отнести их к надсубдукционной субщелочной серии пород калиевого ряда.

\section{ЗАКЛЮЧЕНИЕ}

Изучение петрографических, минералогических и геохимических особенностей К-трахиандезибазальтов показало, что они имеют явные признаки надсубдукционного происхождения. Это глубоко дифференцированные породы, характеризующиеся значительным фракционированием $\mathrm{Pl}$, вероятно, за счет дегазации $\mathrm{H}_{2} \mathrm{O}$ в малоглубинной камере.

В то же время, изучение радиогенных изотопных характеристик $\mathrm{Pb}, \mathrm{Sr}$ и $\mathrm{Nd}$ K-трахиандезибазальтов свидетельствует об их мантийном происхождении и отсутствии влияния земной коры на их составы.

Сравнительный анализ нормированного распределения несовместимых элементов К-трахиандезибазальтов внутриплитных, рифтогенных и надсубдукционных умереннокалиевых базальтов и андезибазальтов показал, что по геохимическим характеристикам источник К-трахиандезибазальтов наиболее близок к источнику надсубдукционных умереннокалиевых пород Камчатки.

Основными отличиями в распределении несовместимых элементов умереннокалиевых базальтоидов и К-трахиандезибазальтов являются более высокие отношения $\mathrm{Nb} / \mathrm{Yb}, \mathrm{Rb} / \mathrm{Ba}, \mathrm{Rb}$-максимумы, Sr-минимумы и повышенные содержания всех несовместимых элементов в последних. 
Sr-минимумы на спайдердиаграммах K-трахиандезибазальтов, вероятно, связаны с фракционной кристаллизацией плагиоклаза.

Обогащение источника К-трахиандезибазальтов несовместимыми элементами обусловлено фракционной кристаллизацией плагиоклаза и привнесением несовместимых элементов-примесей в результате дегидратации субдукционной плиты.

Рассмотренные геохимические особенности K-трахиандезибазальтов и островодужных умереннокалиевых базальтов и андезибазальтов свидетельствуют о разных уровнях плавления мантийных источников сравниваемых пород и гетерогенности мантии под Ключевской группой вулканов.

Геохимические особенности К-трахиандезибазальтов позволяют отнести их к надсубдукционной субщелочной формации калиевого ряда.

Авторы выражают благодарность академику С.А. Федотову, академику Е.И. Гордееву, сотруднику вулканологической обсерватории университета г. Фербенкс (штат Аляска, США) П.А. Избекову, старшему научному сотруднику к.г.-м.н. Г.Б. Флерову, старшему научному сотруднику к.г-м.Н. А.О. Волынец за предоставленные материалы, заведующему Лабораторией динамической вулканологии д.г.-м.н. И.В. Мелекесцеву, ведущему научному сотруднику к.Г.-м.н. Л.И. Гонтовой, Д.г--м.н. Ю.А. Костицину за плодотворное обсуждение. Выполненные исследования были бы невозможны без активного участия ведущего программиста И.М. Романовой, старшего научного сотрудника В.Н. Двигало, научного сотрудника В.В. Ананьева, ведущего инженера С.В. Москалевой, старшего инженера В.В. Пантилеевой, инженера В.С. Хубуная, инженера А.В. Сокоренко. Всем перечисленным сотрудникам ИВиС ДВО РАН, а также начальникам полевых отрядов А.Б. Белоусову, Д.П. Савельеву, Ю.В. Демянчук, и зам. директора ИВиС ДВО РАН Я.Д. Муравьеву авторы выражают благодарность.

Работа выполнена при поддержке грантов РФФИ (№ 13-05-12090 и 13-05-00640).

\section{СПИСОК ЛИТЕРАТУРЫ}

Альмеев P.P. Геохимия магматизма вулкана Безымянный: признаки мантийного источника и условия фракционирования исходной магмы / Автореф. дис. ... канд. геол.-минер. наук. М., 2005. 26 с.

Арискин А.А., Бармина Г.С., Озеров А.Ю., Нильсен Р.Л. Генезис высокоглиноземистых базальтов Ключевского вулкана // Петрология. 1995. Т. 3. № 5. С. 496-521.

Берзина А.П., Берзина А.Н., Гимон В.О. и др. Шахтаминская Мо-порфировая рудно-магматическая система (Восточное Забайкалье): возраст, источники, генети- ческие особенности // Геология и геофизика. 2013. T. 54. № 6. С. 764-786.

Большое трешинное Толбачинское извержение. Камчатка. 1975-1976 / Под ред. Федотова С.А. М.: Наука, 1984. $638 \mathrm{c}$.

Волынеи, А.О., Мельников Д.В., Якушев А.И. Первые данные о составе продуктов Трещинного Толбачинского извержения им. 50-летия ИВиС (Камчатка) // ДАН. 2013. Т. 452. № 3. С. 303-307.

Волынеи О.Н. Петрология и геохимическая типизация вулканических серий современной островодужной системы / Автореф. дис. ... доктора геол.-минер. наук. М., $1993.67 \mathrm{c}$.

Волынец О.Н., Антипин В.С., Перепелов А.Б. и др. Геохимия вулканических серий островодужной системы в приложении к геодинамике (Камчатка) // Геология и геофизика. 1990. № 5. С. 3-13.

Волынеи О.Н., Карпенко С.Ф., Кэу Р.У., Горринг М. Изотопный состав поздненеогеновых K-Na щелочных базальтоидов Восточной Камчатки: отражение гетерогенности мантийного источника // Геохимия. 1997. № 10. С. 1005-1018.

Волынеи О.Н., Колосков А.В., Виноградов В.И. идр. Изотопный состав стронция и кислорода в позднекайнозойских $\mathrm{K}-\mathrm{Na}$-щелочных базальтах внутриплитного геохимического типа, Камчатка // Петрология. 1995. T. 3. № 2. C. 207-213.

Волынец О.Н., Мелекесиев И.В., Пономарева В.В., Ягодзински Дж. М. Харчинский и Заречный вулканы уникальные центры позднеплейстоценовых магнезиальных базальтов на Камчатке: вещественный состав вулканических пород // Вулканология и сейсмология. 1999. № 1. C. 31-45.

Гордеев Е.И., Карпов Г.А., Аникин Л.П. и др. Алмазы в лавах Трещинного Толбачинского извержения на Камчатке // ДАН. 2014. Т. 454. № 2. С. 204-206.

Гордеев Е.И., Муравьев Я.Д., Самойленко С.Б. и др. Трещинное Толбачинское извержение в 2012-2013 гг. Первые результаты // ДАН. 2013. Т. 452. № 5. С. 562-566.

Двигало В.Н., И.Ю. Свирид, А.В. Шевченко. Первые количественные оценки параметров Трещинного Толбачинского Извержения 2012-2013 гг. по данным аэрофотограмметрических наблюдений // Вулканология и сейсмология. 2014. № 5. С. 3-11.

Ермаков В.A. Формационное расчленение четвертичных вулканических пород. М.: Недра, 1977. 223 с.

Ермаков В.А., Важкеевская А.А. Вулканы Острый и Плоский Толбачик // Бюлл. вулканол. станций. № 49. Новосибирск: Наука. Сибирское отделение, 1973. C. 43-53.

Ермаков В.А., Гонтовая Л.И., Сенюков С.Л. Тектонические условия и магматические источники нового Толбачинского трещинного извержения (п-ов Камчатка) // Геофизические процессы и биосфера. 2014. Т. 13. № 1. C. $5-33$.

Интерпретация геохимических данных // Под ред. Склярова Е.В. М.: Интермет Инжиниринг, 2001. 288 с. 
Кокс К.Г., Белл Дж.Д., Панкхерст Р.Дж. Интерпретация изверженных горных пород. М.: Недра, 1982. 416 с.

Колосков А.В., Флеров Г.Б., Перепелов А.Б. и др. Этапы эволюции и петрология Кекукнайского вулканического массива как отражение магматизма тыловой зоны Курило-Камчатской островодужной системы. Часть. 1. Геологическое положение и состав вулканических пород // Вулканология и сейсмология. 2011. № 5. С. 17-41.

Мархинин Е.К., Стратула Д.С., Абдурахманов А.И. Волнистые лавовые потоки вулкана Плоский Толбачик // Бюл. вулканол. станций на Камчатке. № 49. Новосибирск: Наука, 1973. С. 77-82.

Миронов Н. Л. Происхождение и эволюция магм Ключевского вулкана по данным изучения расплавных включений в оливине / Автореф. дис. ... канд. геол.минер. наук. М.: ГЕОХИ РАН, 2009. $31 \mathrm{c.}$

Миронов Н.Л., Портнягин М.В. Содержание $\mathrm{H}_{2} \mathrm{O}$ и $\mathrm{CO}_{2}$ в исходных магмах Ключевского вулкана по данным изучения расплавных и флюидных включений в оливине // Геология и геофизика. 2011. Т. 52. № 11. C. $1718-1735$.

Перепелов А.Б. Геохимия позднекайнозойских высококалиевых вулканических серий островодужной системы Камчатки / Автореф. дис. ... канд. геол.-минер. наук. Иркутск, 1989. 26 с.

Перепелов А.Б. Неогеновый субщелочной магматизм Срединного хребта Камчатки: этапы инверсии островодужного и рифтогенного геодинамических режимов (вулкан Теклектунуп) // Плюмы и проблема глубинных источников щелочного магматизма. Иркутск, 2003. C. 242-278.

Перепелов А.Б. Неоген-четвертичный шошонит-латитовый магматизм Срединного хребта Камчатки: вулкан Теклетунуп (геохимия, петрология, геодинамическая позиция) // Вулканология и сейсмология. 2005. № 1. C. 22-36.

Перепелов А.Б. Кайнозойский магматизм Камчатки на этапах смены геодинамических обстановок / Автореф. дис. ... доктора геол.-минер. наук. Иркутск, 2014. 41 с.

Перепелов А.Б., Пузанков М.Ю., Иванов А.В. и др. Базаниты горы Хухч - первые минералого-геохимические данные, по неогеновому K-Na щелочному магматизму Западной Камчатки // ДАН. 2006. Т. 408. № 6. С. 795-799.

Перепелов А.Б., Пузанков М.Ю., Иванов А.В. и др. Неогеновые Базаниты Западной Камчатки: минералогогеохимические особенности и геодинамическая позиция // Петрология. 2007. Т. 15. № 5. С. 524-546.

Петрографический кодекс: магматические, метаморфические, метасоматические, импактные образования. СПб.: ВСЕГЕИ, 2009. 200 с.

Пийп Б.И. Новый побочный кратер вулкана Толбачик // Бюлл. вулканол. станций на Камчатке. № 13. М.: АН CCCP, 1946. C. 10-21.

Рощина И.А., Шевалеевский И.Д., Коровкина Н.А. и др. Рентгенофлуоресцентный анализ образцов горных пород переменного состава // Советская Геология. 1971. № 10. C. $42-53$.
Соболев А.В., Соболев С.В., Кузьмин Д.В. и др. Механизм образования сибирских меймечитов и природа их связи с траппами и кимберлитами // Геология и геофизика. 2009. Т. 50. № 12. С. 1293-1334.

Федотов С.А., Славина Л.Б., Сенюков С.Л., Кучай М.С. Сейсмические процессы и перемещение магм, происходившие при Большом трещинном Толбачинском извержении 1975-1976 гг. и Трещинном Толбачинском извержении 2012-2013 гг. (п-ов Камчатка) // Геофизические процессы и биосфера. 2014. Т. 13. № 3. С. 5-30.

Ханчук А.И., Иванов В.В. Мезо-кайнозойские геодинамические обстановки и золотое оруденение Дальнего Востока России // Геология и геофизика. 1999. Т. 40. № 11. C. 1635-1645.

Хубуная С.А., Богоявленский С.О., Новгородиева Т.Ю., Округина А.М. Минералогические особенности магнезиальных базальтов как отражение фракционирования в магматической камере Ключевского вулкана // Вулканология и сейсмология. 1993. № 3. С. 46-68.

Хубуная С.А., Гонтовая Л.И., Соболев А.В., Низкоус И.В. Магматические очаги под Ключевской группой вулканов (Камчатка) // Вулканология и сейсмология. 2007. № 2. C. 32-54.

Хубуная С.А., Соболев А.В. Первичные расплавы известково-щелочных магнезиальных базальтов Ключевского вулкана (Камчатка) // ДАН. 1998. Т. 360. № 1. C. $100-102$.

Bravo M.S., M.J. O Hara. Partial Melting of phlogophite-bearing synthetic spinel - and garnet lherzolites //Phys. Chem. Earth. 1975. V. 9. P. $845-854$

Flower M.F. Mantle extrusion: a model for dispersed volcanism and DUPAL-like asthenosphere in East Asia and the West Pacific / Eds Flower M.F., Tamaki K., Hoang N. // Mantle dynamics and plate interactions in East Asia // Geodynamics. 1998. № 27. P. 67-85.

Gill J.B. Geochemistry of Viti Levu, Fiji, and its evolution as an island arc // Contr. Mineral. Petrol. 1970. V. 27. P. 179.

Green D.H., Ringwood A. E. Genesis of calc-alkaline igneous rocks suite // Contr. Miner. Petrol. 1968. V. 18. № 2. P. $105-162$

Hofmann A.W. Chemical differentiation of the Earth: the relationship between mantle, continental crust, and oceanic crust // Earth Planet. Sci. Lett. 1988. V. 90. P. 297-314.

Holm P.E. The geochemical fingerprints of different tectonomagmatic environments using hydromagmatophile element abundences of tholeiitic basalts and basaltic andesites // Chem. Geol. 1985. V. 51. № 3/4. P. 303-323.

Kersting A.B., Arculus R.J. Klyuchevskoy Volcano, Kamchatka, Russia; the role of high-flux recharged, tapped and fractionated magma Chamber (s) in the genesis of high$\mathrm{A}_{2} \mathrm{O}_{3}$ from high-MgO basalt // J. Petrol. 1994. V. 35. № 1. P. $1-41$.

Karandashev V.K., Turanov A.N., Orlova T.A. et al. Use of the inductively coupled plasma mass spectrometry for element analysis of environmental objects // Inorg. Mater. 2008. V. 44. P. 1491-1500.

Lee Cin-Ty A., Luffi P., Plank T. et al. Constraints on the depths and temperatures of basaltic magma generation on 
Earth and other terrestrial planets using new thermobarometers for mafic magmas // Earth and Planetary Science Letters. 2009. doi:10.1016/j. eps1.2008.12.020

Mysen B., Boettcher A.L. Melting of hydrous mantle: II. Geochemistry of crystals and liquids formed by anatexis of mantle peridotites at high pressure and high temperatures as a function off cohtrolled activitics of water, hydrogen and carbon dioxide // J. Petrol. 1975. V. 16. P. 543-593.

Pearce J.A., Stern R.J., Bloomer S.H., Fryer P. Geochemical mapping of the Mariana arc-basin system: implication for nature and distributions of subducted components // Geochemistry, Geophysics, Geosystems (G3 ). 2005. V. 6. doi: 10.1029/2004GC000895

Sun S.S., McDonough W.F. Chemical and isotopic systematic of oceanic basalts: implication for mantle composition and processes // Magmatism in Ocean Basins. Geological Society Special Publication № 2. Blackwell Scientific Publications. 1989. P. 313-346.
Tatsumi Y., Hamilton D.L., Nesbitt R.W. Chemical characteristics of fluid phase released from a subducted lithosphere and origin of arc magmas: Evidence from high-pressure experiments and natural rocks // J. of Volcanol. and Geotherm. Res. 1994. V. 29. P. 293-309.

Wright T.L., Doherti P.C. A linear programming and least squares computer method for solving petrologic mixing problem // Geol. Soc. Am. Bull. 1970. V. 81. № 7. P. 95-106.

Wood D.A. A variably veined suboceanic mantle-genetic significance for mid-ocean ridge basalts from geochemical evidence // J. Geology. 1979. V. 7. № 3. P. 499-503.

Zelenski M., Malik N., Taran Yu. Emissions of trace elements during the 2012-2013 effusive eruption of Tolbachik volcano, Kamchatka: enrichment factors, partition coefcients and aerosol contribution // J. of Volcanol. and Geotherm. Res. 2014. V. 285. P. 136-149. 